\title{
Özerk Benlikli Birey Yetiştirme Sürecinde Çağdaş Dil ve Edebiyat Öğretimi Ortamlarının (Türkçe/Türk Dili ve Edebiyatı) Önemi
}

\section{The Importance of Modern Language and Literature (Turkish Language/ Turkish Language and Literature) Teaching Environments in the Process of Developing Autonomous Self in Individuals}

\author{
Canan Aslan, Ankara Üniversitesi Eğitim Bilimleri Fakültesi, Güzel Sanatlar Eğitimi Bölümü, \\ caslan@ankara.edu.tr
}

\begin{abstract}
öZ. Dil ve edebiyat öğretimi ortamlarında daha çok ezbere ve bilgi vermeye dönük öğretim anlayışının yürütüldüğü, öğretimin edebiyat tarihi bilgisine indirgendiği, özerk benlikli birey yetiștirme çabalarının işe koşulmadığı bilinmektedir. Özerk benlik duygusu gelişmiş birey yetiştirmede çağdaş dil ve edebiyat öğretimi ortamlarının nasıl düzenlemesi gerektiği sorununu tartışmak ve bu sorunun çözümüne dönük kimi öneriler getirmek amacıyla ele alınmış bu yazıda, öncelikle özerk benlikli bireyin hangi özelliklere sahip olduğu, bu özelliklere sahip olmanın kişinin kendisi ve toplum yaşamı açısından taşıdığı önem ele alınmıştır. Ardından birey yetiştirme sürecinde çağdaş anlayıșla yapılandırılmış dil ve edebiyat öğretiminin önemi ve nasıl yapılması gerektiği üzerine odaklanılmış ve bu konudaki ilkeler ortaya konmaya çalışılmıştır. Bu amaçla dil ve edebiyat öğretimi ortamlarında kullanılması gereken metinlerden sorulara, etkinliklerden çocuk/gençlik edebiyatı yapıtlarına, dilbilgisi öğretiminden öğretimde kullanılması gereken araç gereçler ile yöntem ve tekniklere, yazılı anlatım çalışmalarından diğer sanatların olanaklarına, ders kitaplarından ödevlere ve değerlendirmeye kadar konunun birçok önemli boyutu irdelenmiştir.

Anahtar Kelimeler. Birey, Özerk Benlikli Birey, Dil ve Edebiyat Öğretimi, Türkçe Öğretmeni, Edebiyat Öğretmeni.
\end{abstract}

\begin{abstract}
In language and literature teaching environments, an approach based on rote learning and transfer of knowledge is embraced, teaching is reduced to knowledge of literature history and no effort is made to develop autonomous self in individuals. This research, which is aimed at discussing the problem of how modern language and literature teaching environments should be organized to develop autonomous self in individuals and offering solutions to this problem, examines characteristics of autonomous individuals and the importance of having these characteristics for individuals and social life. This research also focuses on the importance of modern language and literature teaching and how it should be performed, and attempts to provide relevant principles. To this end, such important dimensions of the topic as texts, questions, activities and children's/ young adult books that should used in language and literature teaching environments; grammar teaching and relevant methods, techniques and materials; writing activities and other art activities; homework, textbooks and evaluation.

Keywords. Individual, Autonomous Individual, Language and Literature Teaching, Turkish Language Teacher, Literature Teacher.
\end{abstract}

\section{SUMMARY}

Introduction: One of the main aims of modern language and literature teaching is to educate individuals who understand and tell what they read/ listen completely and accurately, who have developed thinking skills and who complete their individualization process. However, in language and literature teaching environments, an approach based on rote learning and transfer of knowledge is embraced, teaching is reduced to knowledge of literature history and no effort is made to develop autonomous self in individuals. The main purpose of this research is to reveal how language and literature teaching should be performed to develop autonomous self in individuals and which principles should be pursued in teaching environments.

Individual and Autonomous Individual: An individual has similar and common intellectual, emotional and other characteristics with other people in society and also some unique 
characteristics distinguishing himself or herself from other people. An autonomous individual, on the other hand, sets own limits based on his or her rights and values; is capable of displaying autonomous behaviours; controls his or her own life; respects the self; has a high level of awareness; makes right decisions and evaluations; does not feel obliged to behave as the other people in society; is free in his or her feelings, thoughts, choices, decisions and behaviours; and refuses to submit to an authority.

Importance of Developing Autonomous Self in Individuals and Education: It is very important that people in society become autonomous individuals because decisions individuals make determine living standards and conditions of people in society. If societies cannot educate autonomous individuals, people make partial, controlled, unconscious and thus wrong decisions about issues having important effects on social life. Modern language and literature teaching environments thanks to their nature and materials they use can make an important contribution to educating autonomous individuals.

Language and Literature Teaching in the Process of Developing Autonomous Self in Individuals: Various types of texts appropriate for students' age and developmental abilities, interests and likes, needs and experiences, quality children's and young adult books and literaturebased activities should be used in language and literature teaching environments to contribute to children's emancipation and individualization process. It is important to ask open-ended questions in examinations and in class activities to provide students with opportunities of making decisions and require them to justify their decisions. Activities should provide students' with opportunities of relating what they learn with real life. Grammar should not be taught based on rote learning and as a set of rules, but be text-based, creative, thought provoking and productive. Students should be aware of the contributions of learning grammar. Using visual and audio materials appropriate for students' interests and likes (literary work, science and art magazines, full-length films, short films, comics, pictures, sculptures, paintings, videos and other art work) is important in terms of becoming an autonomous individual. Teachers should use methods and techniques that can provide students with opportunities of participating and sharing their feelings and thoughts. Making students write their feelings and thoughts about topics appropriate for their interests, likes, needs, age and developmental abilities can contribute to their individualization. In writing activities teachers should make sure that students reflect their rights in their writings and defend their feelings and thoughts freely with individual examples and justifications, and encourage students to this end. Textbooks should be prepared carefully in terms of both content and external structure and visual design. Students should be assigned homework which they can make efficiently by themselves and which serves to reach the aims of the course. Students should be asked to complete this homework by themselves. When students make homework by themselves and see that they are capable of this, they become more self-confident and make progress in individualization. Language and literature teachers should cooperate with other art teachers such as painting, visual arts or music teachers.

Conclusion: Modern language and literature teaching environments make an important contribution to becoming an individual. While reaching the aims of the course, language and literature teachers should organize teaching environments in a way to provide opportunities of becoming an individual. Language and literature teaching environments should also be reassuring, warm, sincere, supportive and free so that children/ young adults become autonomous individuals.

\section{GÍRIS}

Toplumu oluşturan kişilerin özerk birey niteliğini kazanması çok önemlidir; çünkü bireylerin aldığı kararlar o toplumda yaşayan insanların yaşam standartlarını ve koşullarını belirler. Toplumlar özerk benlik duygusu gelişmiş bireyler yetiştir(e)mezlerse toplum yaşamını belirleyen önemli konularda taraflı, güdümlü, ezbere, bilinçsizce ve doğal olarak yanlış kararlar alınır. İnsanın özerk birey olabilmesinde çağdaş anlayışla yapılandırılmış dil ve edebiyat öğretimi ortamları, kullandığı araçlardan ve doğasından kaynaklı önemli katkılar sağlayabilir. Okuduğunu/dinlediğini 
tam ve doğru anlayan, kendini doğru ve etkili anlatan, düşünme becerileri gelişmiş, yaratıcı, bireyleşme sürecini tamamlamış kişiler yetiştirmek çağdaş dil ve edebiyat öğretiminin ulaşmak durumunda olduğu en önemli amaçlar arasındadır. Bununla birlikte bu ortamlarda daha çok ezbere ve bilgi aktarmaya dönük öğretim anlayışının yürütüldüğü, öğretimin edebiyat tarihi bilgisine indirgendiği, özerk benlikli birey yetiştirme çabalarının işe koşulmadı̆̆ı bilinmektedir.

Özerk benlik duygusu gelişmiş birey yetiştirme sürecinde çağdaş dil ve edebiyat öğretimi ortamlarının nasıl düzenlemesi gerektiği sorununu tartışmak ve bu sorunun çözümüne dönük kimi öneriler getirmek amacıyla ele alınmış bu yazıda sırasıyla; özerk benlikli bireyin hangi özelliklere sahip olduğu, bu özelliklere sahip birey olmanın kișinin kendisi ve toplum yaşamı açısından taşıdığı önem, birey yetiştirme sürecinde çağdaş anlayışla yapılandırılmış dil ve edebiyat öğretiminin önemi ve tüm boyutlarıyla öğretimin nasıl yapılması gerektiği üzerine odaklanılmış, bu konudaki ilkeler ortaya konmaya çalışılmıştır.

\section{Birey ve Özerk Benlikli Birey}

Ruhbilim terimi olarak birey (Alm. Individuum, n; Fr. individu, m; İng. individual; esk. fert), insan topluluklarını oluşturan, insanların benzer ve ortak yanlarını kendinde taşımakla birlikte kendine özgü ayırıcı özellikleri de bulunan tek can, fert (TDK, 2015; Dil Derneği Türkçe Sözlük, 2012:229; TÜBA Türkçe Bilim Terimleri Sözlüğü); toplumbilim terimi olaraksa, "Düşünsel, duygusal, istençsel nitelikleri toplumsal ilişkileriyle belirlense de kendi başına bir varlığı ve kimliği olan insanların her biri" (TÜBA Türkçe Bilim Terimleri Sözlüğü) olarak tanımlanmaktadır. Tanımlardan da anlaşılacağı üzere birey, yaşadığı toplumdaki diğer insanlarla düşünsel, duygusal ve diğer yönlerden benzer ve ortak yanlar taşımakla birlikte, onlardan farklı kendine özgü ayırıcı özellikleri de olan kişidir, denebilir.

Benlik, kişinin dış ve iç dünyanın gereklerini, gerçeklerini tanımasını, bunlara göre davranmasını sağlayan işlevlerin (algılama, algılanan uyaranlar arasında bağlar kurma, nedensonuç ilişkilerini belirleme, bellek, gerçeği değerlendirme gibi bilişsel yetilerle birlikte, korku, sevinç, üzüntü, acı çekme gibi değişik duygusal tepkilerle uyum için eyleme geçebilme yetileri) tümü olarak adlandırılabilir. Dış ve iç dünyayı algılayan, dış dünyanın koşulları ile bireyin iç dünyasındaki dürtüleri, istekleri, yasakları değerlendiren, kişinin kendi içinde ve çevresinde uyumlu olmasını sağlayan işlevlerin tümü "benlik" denilen bu soyut kavramsal yapıyı oluşturur (Öztürk, 2013:55). Kişinin kendine ilişkin algılarının düzenlenmiş ve tamamlanmış biçimidir ve kişiliğin öznel yanını oluşturur. Kişiyi o kişi yapan, başkalarından ayıran duygu, tutum ve davranışların tümünün örgütlenmiş bütünlüğüdür (Rogers, 1951; Adams, 1995; Yörükoğlu, 2004). Benlik kavramı, bir bireyin kendini görüşüdür. Yalnızca ona özgü tutumlardan, duygulardan, inançlardan, algılardan, değerlerden, davranıșlardan ve diğer özelliklerden ibaret kendine ilișkin görüşüdür. Benlik, disiplin ve sevgi aracılığıyla anne-babadan, uygun davranışı gösterme baskısıyla yaşıtlardan, başarı ya da başarısızlıkla okul yaşantılarından ve birçok başka olaydan etkilenir. Anne babalar çocuklarına kendi yetenekleri çerçevesinde kendi davranışlarını yönetme olanağı verir ve rehberlik yaparlarsa çocuklar sağlıklı bir özerklik duygusu geliştirir. Eğer çocuklara yetkenin (otoritenin) kim olduğunu sürekli gösterir ve onları utandırarak boyun eğmeye zorlarlarsa çocuklar kendilerinden kuşku duyar ya da kendilerini yıllarca engelleyecek utanç duygusu geliştirirler (Gander ve Gardiner, 1998).

Özerklik ise, birtakım seçenekler arasından kendi seçimini yapabilme, karar verebilme ve kendi kendini yönetebilir olma durumudur. Özerklik duygusu, bireyin yalnızca ayrımlaşmış bir varlık olduğunun algılanması değildir. Aynı zamanda, karşıt dürtü ve eğilimleri arasında bir seçim yapabilmesi; benlik saygısını yitirmeden, utanç ve kuşkuya kapılmadan kendi kendini denetleyebilmesidir. Özerklik duygusunun benlik içinde yapılanması çocuğun kendine ve çevresine karşı temel güven duygusunun gelişmesine bağlıdır. Özerk benlik duygusu olan kişinin toplumsal sorumlulukları şu şekilde sıralanabilir (Öztürk, 2013:49-60):

- insanların eşitliğini, özgürlüğünü benimsemiş olmak,

- insanlara saygl, sevgi beslemek,

- insan haklarının yanında olmak, 
- toplumculuk,

- bilime bağlılık,

- kendisinin ve başkalarının özerkliğini korumak,

- irkçılığa karşı oluş,

- her türlü ayrımcılığa karşı olmak,

- her türlü bağnazlığa karşı olmak,

- insanın insanı sömürmesine karşı olmak,

- işkenceye karşı olmak,

- adaletsizliğe karşı olmak,

- savaşa, nükleer silahlanmaya karşı olmak,

- doğanın yok edilmesine karşı olmak.

İnam’a (2016) göre özerk insan, "iç dünyası" egemenliğine, istiklaline kavuşmuş, bağımsız bir kişidir. Özgürlüğünün erki kendindendir. Özerk, "başına buyruk" biri değildir; özerkliğinin diğer insanların özerkliğine bağlı olduğunu bilir. Cüceloğlu (1998:391-392), özerk benlikli bireyi, "gelişmiş insan" olarak adlandırır. Gelişmiş insan, "Yaşamına anlam veren temel ilke ve değerlerin bilincinde olan ve bu bilinçle duygu, düşünce ve davranışını süreçleyen kişi" dir. Ona göre "gelişmiş insan"ın tam tersi ise yaşamına anlam veren temel ilke ve değerlerin bilincinde olmayan, dışarıdan dayatılmış duygu, düşünce ve davranış kalıplarını eleştirel düşünce süzgecinden geçirmeden uygulayan "kalıplanmış insan"dır. Öztürk (2013:63-145), "kalıplanmış insan" yerine "kul benlik" ifadesini kullanır. Ona göre bir ideolojiye ya da yetkeye körü körüne boyun eğme, kul benliğin en belirgin göstergesidir. İktidara, paraya, mala mülke, uyuşturucu maddelere aşırı tutkusu olan kişiler, kul benlik duygusu içindedir. Özgür düşünebilme, özgür seçim yapma, karar verebilme, sorgulayabilme, insanı, toplumu, doğayı, yeni şeyleri merak etme, öğrenmeye çalışma, olaylara eleştirel gözle bakarak özgürce sorular sorma, tartışma ve araştırma gibi kişilik özelliklerinin ve eğiliminin eksikliği/yokluğu ise, kul benliğin diğer belirtileri arasındadır. Kişide kendi benliğini geliştirmek için bir ereğin bulunmaması, yetkeye bağımlılık, bilime ve sanata ilginin azlığı da yine kul benliğin belirtileri arasındadır.

Tüm bu tanımlama ve belirlemelerden sonra özerk benlikli birey; sınırları kendi doğrularıyla ve değerleriyle diğerlerinden ayrımlaşmış, özerk davranışlar gösterebilme becerisini kazanmış; etkin, girişken, kararsızlık yaşamadan kendini (dürtü ve gereksinimlerini) yönetebilen ve yaşamını denetleyebilen, kendi benliğine saygıll, özdeğer duygusu gelişmiş, canlı, devingen, atılgan, çalışkan, ekonomik bağımsızlığını kazanmış, öğrenmeye meraklı, soran, araştıran, özgürce düşünen, farkındalık düzeyi gelişmiş kimse biçiminde tanımlanabilir. Özerk benlikli birey; gelişmiş insandır, sorunların özüne inerek onları çeşitli açılardan irdeler ve bunları önyargısız biçimde anlamaya çalışır. Olaylara/durumlara kendi düşünce yapısına uymuyorsa nesnel, bağımsız ve özgürce karşı çıkar. Konuya saplantısız, önyargısız ve akılcı yaklaşır. Yargılarını erteleyebilir ya da değiștirebilir. Doğruyu yanlıştan, etkiliyi etkisizden, nitelikliyi niteliksizden, yararlıyı yararsızdan, iyiyi kötüden ayırır. Sağlıklı seçim ve değerlendirmeler yapar, kararlarını özgürce alır. Sürekli kendisini geliştirirken insanların görüşlerine/haklarına saygıyla ve hoşgörüyle yaklaşır. Zihinsel etkinliklerde bulunur; düşünür, sorgular, bilimsel kuşku duyar. Karşılaștırmalar yapar, mantıklı çıkarım, yorum ve değerlendirmelerde bulunur. Sonuçlara, bulgulara dayanarak varır. Olay, durum ve sorunlarını sürekli sorgulayarak ve mantıklı ölçütler kullanarak çözümlemeye, bunları bildikleriyle karşılaştırarak anlamaya çalışır. Sorunları dizgesel olarak inceleyip sonuçları kimsenin etkisinde kalmadan değerlendirir. Vatandaşlık haklarının ve topluma karşı olan sorumluluklarının bilincindedir. Özerk benlik duygusu gelişmiş birey, kendini tümüyle toplumdaki diğer kişiler gibi hareket etmek zorunda hissetmeyen; duygularında, düşüncelerinde ve davranışlarında çeşitli güçlerin baskısından/etkisinden kurtulmuş; kararlarında özgürleşmiş, bağlı olduğu güçlerden göreceli olarak bağımsızlaşmış kişidir. Üst düzey düşünme becerileri gelişmiş, farkındalığı yüksek, duyarlık kanalları açık, gizil yeteneklerinin farkında ve bunları geliştirmeye istekli, sanata ve bilime ilgi duyan, kendisini ve çevresini anlamaya çalışan, sorgulayan, anlamadan inanmayan, özgür düşünebilen ve özgürce seçim yapabilen kişidir. 


\section{1. Özerk Benlikli Birey Yetiştirmek Neden Önemlidir?}

Öztürk (2013:199)'e göre bireysel ve toplumsal düzeyde her türlü değişmenin ve gelişmenin önde gelen koşulu bilinçlenmek, eleştiri ve özeleştiri yapabilmektir. Özeleştiri yapabilmek ve sorunların bilincine varabilmek özerk benlik duygusunun varlığına bağlıdır. Değişim ve gelişim açısından bilinçli bir toplumun ortaya çıkması, bireylerde bu duygunun gelişmesini önleyen etkenlerin bilinmesini gerektirir. Cüceloğu'na (1998:378) göre, kendini geliştirmenin iki düzeyi vardır:

1. Kalıplarının bilincine varmak ve onların etkisinden kurtulup kendi temel ilke ve değerlerini keşfetmek,

2. Bu temel ilke ve değerleri günlük yaşama etkili biçimde uygulayabilmek için kendini yenilemek.

Kendisini ve çevreyi değiştirerek özerk biçimde uyum yapabilme yetisi insana özgüdür. Benliğin özerkliğini kazanabilmesi için, bağımlı olduğu nesnelerden, kendine egemen olabilecek, sınırlarını zorlayacak birtakım güçlerden, göreceli olarak bağımsızlaşması gerekir. Benlik özerkliğini olumsuz etkileyen ya da özerklik duygusunun sağlam gelişimini önleyen etkenler; "ağır baskıcı, yoksun bırakıcı, engelleyici, çocuğun doğal araştırma, öğrenme ve girişim eğilimlerini kısıtlayan, korkuya dayanan, baskıcı çocuk yetiştirme yöntemleri, aşırı koruyucu aile ve toplum" gibi çevre koşullarıdır (Öztürk, 2009b).

Özerk benlikli bireyin gelişimi, öncelikle kişiyi kuşatan toplumsal koşullara, onun düşünsel ve duygusal ilişsilerine/çabalarına sıkı sıkıya bağlıdır. Başka deyişle, bireyin yetişmesi, içinde yaşadığı çevrenin/toplumun belli bir düşünsel gelişim çizgisine ulaşmasını koşullar. Öztürk’e (2013:11-12-16) göre “Çocuğun bilseme duygusunu ve araştırıcılığını besleyen koşullar onun doğuştan gelen yetilerinin yanı sıra ona uyarıcı ve öğretici bir çevre sağlayan, onun özerk kimlik oluşumunu destekleyen, özgürce sormaya ve öğrenmeye değer veren aile ve okuldur. Çocukların doğal gelişimsel gizilgüçleri (potansiyelleri) ancak özerk benlik duygusunu besleyen eğitim ve özgürlük ortamlarında açı̆̆a çıkabilir."

Özetle söylemek gerekirse, toplumu oluşturan kişilerin özerk birey niteliğini kazanmaları çok önemlidir; çünkü bireylerin aldı̆̆ı kararlar o toplumda yaşayan insanların yaşam standartlarını ve koşullarını belirler. Birey olamamış, bireyleşme sürecini tamamlayamamış, başkalarının güdümünde olan insanların toplumsal yaşam adına vereceği kararlar son derece tehlikeli olabilir. Başka bir söyleyişle, eğer toplumlar özerk benlik duygusu gelişmiş bireyler yetiștir(e)mezlerse bu durum, yaşamın her alanında yanlış kararların alınmasına neden olur. Toplum yaşamını belirleyen önemli konularda taraflı, güdümlü, ezbere, bilinçsizce, duyarsızca ve doğal olarak yanlış kararlar alınır. $\mathrm{O}$ toplumda yaşamak da olanaksız hale gelir. Bu durumda bir toplumda geniş kitlelerin bireyleşme sürecini tamamlamış olmaları, yaşamın her alanı açısından büyük önem taşır. Toplumların ve o toplumdaki kurumların özerk olabilmesi, toplumların kültürel, bilimsel, sanatsal yönlerden kalkınabilmesi de toplumun ve kurumun sahip olduğu bireylerin özerk olmasına bağlıdır. İnsanın kalıplarının bilincine varması, bunların etkisinden kurtulup kendi temel ilke ve değerlerini keşfetmesi, bu temel ilke ve değerleri günlük yaşama etkili biçimde uygulayabilmek için kendini yenilemesi ise, ancak eğitimle, eğitimin sunduğu olanaklarla sağlanabilir. Kısaca, eğitimin insana sunacağı en önemli olanaklardan biri, kişinin özerkleşme; başka bir deyişle bağımsızlaşma/özgürleşme sürecine katkıda bulunmasıdır. Bireyi özerkleștirici eğitim ortamlarında öğrenciler derse etkin biçimde katılır, duygularını ve düşüncelerini rahatlıkla ifade edebilir, herhangi bir güvensizlik ve korku yaşamazlar. Farklı düşünce ve anlayışları tartışma, eleştirme, sorgulama ve 
değerlendirme özgürlükleri vardır. Bir sanat eğitimi süreci olan dil ve edebiyat öğretimi, doğası gereği ve kullandığı araçlardan kaynaklı birey yetiştirme konusunda uygun ortamlar yaratabilir.

\section{2. Özerk Benlikli Birey Yetiştirme Sürecinde Dil ve Edebiyat Öğretimi}

Çocuğun, anadilini yetkin biçimde öğrenmesi yalnızca okul başarısını olumlu etkilemez, onun özerkleşerek yaşamın diğer alanlarında da başarılı olmasını sağlar. Türkçe derslerindeki başarı ile diğer derslerdeki başarı arasında anlamlı bir ilişki olduğu bilinmektedir (Güneyli vd., 2010). Başka bir deyişle dilsel becerileri gelişmeyen öğrenciler, ortak iletişim aracının dil olması nedeniyle diğer derslerde de başarısız olmaktadır. $\mathrm{Bu}$ nedenle dil ve edebiyat öğretimi ortamlarında çocuğa öncelikle anlama (okuma-dinleme) ve anlatma (konuşma-yazma) becerilerini kazandırmak, bunlara olabildiğince eșit ve dengeli biçimde yer vermek çok önemlidir. Bununla birlikte bu ortamlarda daha çok ezbere ve bilgi aktarmaya dönük öğretim anlayışının yürütüldüğü, öğretimin edebiyat tarihi bilgisine indirgendiği, özerk benlikli birey yetiştirme çabalarının işe koşulmadığ bilinmektedir (Binyazar, 1983; Göktürk, 1989; Göğüș, 1990; Özdemir, 1990; İpşiroğlu, 1991; Kavcar, 1988; Sever, 2002; Çotuksöken, 2002; Günay, 2006; Özbay, 2002). Okuduğunu/dinlediğini tam ve doğru anlayan/anlatan, yaratıcl, düşünme becerileri gelişmiş, bireyleşme sürecini tamamlamış kişiler yetiştirmek çağdaş dil ve edebiyat öğretiminin ulaşmak durumunda olduğu en genel amaçlar arasındadır. $\mathrm{Bu}$ amaçlara ulaşılabilmesi için dil ve edebiyat öğretmeninin birtakım özellik ve yeterlikleri taşıması gerekir.

\subsection{Birey Yetişmesine Katkıda Bulunacak Dil ve Edebiyat Öğretmenleri Hangi Özellikleri Taşımalı, Öğretimde Nelere Dikkat Etmelidir?}

Çocukların kişilik gelişiminde öncelikle anne-babalar ve eğitim sisteminin en başat bileşeni olan öğretmenler önemli rol oynar. Dil ve edebiyat öğretimi ortamlarında birey yetiştirebilmek için öncelikle öğretmenin kendisinin bireyleșme sürecini tamamlamış olması gerekir. Öğretmen yetiştiren fakültelerde birey olabilmeyi başarmış, birey olmanın öneminin farkında olan öğretmenler yetiştirilmelidir; çünkü bireyleșme sürecini tamamlayamamış bir öğretmenin doğal olarak birey yetiştirme gibi bir kaygısı ve önceliği de olamaz. Öğrencilerinin başkalarınca biçimlendirilmeye uygun nesneler olmalarını istemeyen dil ve edebiyat öğretmeni, dersin amaçlarını gerçekleştirirken her öğretim düzeyinde eğitim ortamını birey yetişmesine olanak sağlayacak, öğrencilerin bireyleşmesine katkı sunacak biçimde düzenleyebilir. Öğrenciye yaklaşımıyla, seçtiği uygun metin ve etkinliklerle; geliştirici, düşündürücü, dönüştürücü sorularla, çocuğa/gence görelik ilkesine uygun edebiyat yapıtlarıyla, nitelikli araç-gereçlerle, çağdaş öğrenme-öğretme yaklaşımlarıyla öğrencilerin bireyleşmesini destekleyebilir. Birey yetişmesini önemseyen dil ve edebiyat öğretmeni, öncelikle öğrencilerini hiçbir ayrım gözetmeksizin (dinsel, ırksal, mezhepsel, dünya görüşü vb.) kendi kültürel özgünlükleri, bireysel değerleri ve farklılıklarıyla sevmeli; onlara değerli olduklarını duyumsatmalıdır. Öğrencilerini kendi dünya görüşüne, kendi değerlerine göre biçimlendirmeye çalışmamalıdır. Derslerinde içten sevgiye ve iletişime, karşılıklı etkileşime, inanca ve güvene çok önem vermelidir. Öğrencilerin duygularında, düşüncelerinde, tasarılarında, kararlarında özgürleşmesini sağlamalı; özgüvenlerini sarsacak davranışlarda bulunmamalıdır. Öğretmen yöresel ağızla konuşan ya da anadili Türkçe olmayan öğrencilerini incitecek davranışlardan kaçınmalı; yapacağı ek etkinlikler ve çalışmalar yoluyla onlara ölçünlü Türkçeyi sevdirerek öğretmelidir.

Dil ve edebiyat öğretmenleri, öğrencileri dille doğal bir biçimde oynama konusunda cesaretlendirmeli; öğrencilerin dilsel atılım ve ilerlemelerini takdir etmelidir (Power ve Hubbard, 2002:108). Öğretmenler diğer derslerin öğretmenleriyle bağlantı kurmalı, derslerini diğer derslerin içerikleriyle bütünleştirerek yürütmelidir (Strickland, Galda ve Cullinan, 2004). Öğrencilerin diğer derslerde öğrendikleri kavramların anlamlarını pekiştiren ve öğrencilerin bu kavramları özgüvenle 
kullanmalarını sağlayan etkinlikler tasarlamalı; öğrencilerinin bireyleşmesi için okul yönetimiyle, zümresiyle, ailelerle, ilgili toplumsal kurum ve kuruluşlarla, bunların dışında resim, görsel sanatlar ve müzik eğitimi gibi diğer sanat öğretmenleriyle de sağlıklı bir işbirliği ve dayanışma içinde olmalıdır. Birey yetiştirilmek istenen sınıflardaki öğrenci sayısının doğal olarak az olması gerekir; çünkü öğrencilerin duygularını, düşüncelerini, tasarılarını gerek yazılı gerekse sözlü olarak anlatabilmeleri için onlara yeterli zamanın verilmesi gerekir.

\subsection{Derslerde Kullanılan Metinler Nasıl Olmalı, Hangi Özellikleri Taşımalıdır?}

Metinleştirme, öncelikle ileti içinde aktarılacakların mantıksal-anlamsal açıdan, ardından da iletiyi taşıyacak olan dilsel kodlamanın biçimsel, dilsel/dilbilgisel açıdan bağıntılı kılınmasıdır (Keçik ve Uzun, 2003). Yazılı ya da sözlü olarak üretilmiş her metnin en temel işlevi iletişimidir; iletişim işlevi olmayan yazılı ya da sözlü bir belge metin değeri taşımaz (Yılmaz, 2010; Günay, 2001). Bağdaşıklık ve tutarlılık (metin merkezli ölçütler) ile amaçlılık, kabuledilebilirlik, bilgisellik, durumsallık ve metinlerarasılık (kullanıcı ya da okur merkezli ölçütler) bir metnin taşıması gereken ölçütlerdir ve bu yedi ölçütten birinin olmaması durumunda metin, iletişim işlevini yerine getiremez. Metin birliklerinin bir araya gelerek oluşturdukları bütünün bir metin olarak nitelenebilmesi için bu ölçütleri karşılaması beklenir (De Beaugrande ve Dressler, 1981). Metinsellik ölçütleri de temelde bir metnin en temel işlevi olan iletişim işlevine gönderimde bulunmaktadır. İletişim işlevini yerine getirebilmesi için bir metnin kendi içinde bağlaşık ve tutarlı olması gerekir (Ülper, 2011). Dil ve edebiyat öğretmenleri, öğrencilerini hem öğretimin ve dersin amaçlarına uygun hem de türünün en iyi örnekleri olan ve anılan metinsellik ölçütlerini karşılayan farklı türdeki metinlerle buluşturmalı, derslerini bu metinler eşliğinde yürütmelidir.

Aslan'a (2010a) göre, öğretmenin derslerde kullandığı metinler eleştirel ve özgür düşünebilmeye, farklı düşünceler üretmeye olanak sağlamalıdır. Metinlerin içerik özelliklerinin öğrencinin yaş ve gelişim düzeyine, ilgi ve beğenisine, gereksinim ve yaşantısına uygun olması; yaşam ve insan gerçekliğini yansıtması gerekir. Metinlerin, çocuğun özerkleşmesine katkı sağlayabilmesi için düşünme becerisinin önündeki engelleri (belli bir otoriteye, inanca ve ideolojiye körü körüne itaat etme, sınırlı ya da az sayıda kanıttan yola çıkarak çok fazla çıkarımda bulunma; başka bir deyişle, aşırı genellemeler ve basitleştirmeler yapma, yeterince seçenek üretmeme, başkaları için olumsuz değerlendirmelerde bulunma, önyargılı, basmakalıp düşünceleri savunma, benmerkezci, dogmatik koşullanmalar, etiketlemeler, acele ulaşılan sonuçlar) barındırmaması gerekir. Bu bağlamda, türü ne olursa olsun, duyma ve düşünme sorumluluğunu okura bırakan; öğrencinin yorumlamasına, kestirimde bulunmasına, değerlendirme ve yorumlar yapmasına ve yaşamla ilişki kurmasına, metindeki olaylar üzerine kendi kararlarını verebilmesine olanak sağlayacak metin seçimi çok önemlidir.

Başarılı dil ve edebiyat öğretmenleri; derslerinde dil ve edebiyat öğretiminin en önemli araçları, vazgeçilmez bileșenleri olan yazınsal nitelikli metinlerin yanı sıra diğer metin türlerinden de yararlanmalı, sanatsal ve bilimsel değeri olan dergiler ile çeşitli gazetelerin kitap ekleri de derslerde inceleme konusu yapılmalıdır. Örneğin, Nadir Nadi'nin "Kendi Kafasıyla Düşünmek" adlı aşağıdaki yazısı dil ve edebiyat öğretimi ortamlarında hem dersin amaçlarına hem de çocuğun/gencin bireyleşme sürecine katkıda bulunabilecek nitelikte bir metindir:

\section{KENDİ KAFASIYLA DÜŞÜNMEK}

Koltuk değneğiyle gezen bir sakat gördük mü, acırız. Sebebi ne olursa olsun, vücut dediğimiz esrarlı (gizemli) makinenin bir uzvunu (organını) koparıp atan kaza, muhayyilemizi (hayal gücümüzü) dehşetle kamçılar. Et ve kemikten bir ayak yerine bir sopa kullanmak mecburiyetinde (zorunda) kaldığı için biçareye (zavallıya) içimiz sızlar.

Takma göz, iğreti kol, parmaksız el bütün uzvi kusurları (organ kusurlarını) kalbimiz (yüreğimiz) burkularak merhametle, șefkatle ve ıstırapla seyrederiz. "Üzerinde âriyet (iğreti) bir şey taşımak, bütün ömrünce onunla yaşamak ne feci!" diye söyleniriz.

Hâlbuki (oysa) kendi kafasıyla düşünmeyerek şuradan buradan toplanmış kırpıntı fikirlerle geçinen zavallıları hesaba bile katmayız. Çünkü kuvvetli (güçlü) bir gövde üzerinde, yağma edilmiş bir banka kasası gibi bomboş duran kafalar, bizi 
alakadar etmez (ilgilendirmez). Bazen belki onlara kızdı̆̆ımız olur. Canlı olan bir beynin bu kadar hareketsiz kalmasına, bu kadar papağanlaşmasına șaşarız. Fakat o adama acımak aklımıza gelmez!

Hatırlamayız ki koltuk değneğiyle dolaşan bir sakat, herhangi bir adamın gideceği yere biraz geç de olsa nihayet (sonunda) gidebilir. Takma diş, iğreti kol, parmaksız el güç de olsa nihayet (sonunda) herhangi bir kimsenin başaracağı bir iși başarabilir.

Ya kendi kafalarıyla düşünemeyenler? Ah, o iğreti fikirlerle yaşamaya çalışan, meselesiz (sorunsuz), ıstırapsız, bomboş ve biçare (zavallı) insanlar!

Nadir Nadi, Sokakta Gürültü Var, 1974, s.100

Dil, düşünceyi yalnızca taşıyan, ileten bir araç olmayıp, düşünceyi yeniden yapılandıran, onu tamamlayan temel bir işlevsel yetidir (Öztürk, 2009a). Bugün Türkçenin karşı karşıya bulunduğu en önemli sorunlardan biri, yabancı sözcük kullanma merakı ve tutkusudur (Kavcar, 2008; Sever, 2002; Aslan, 2006). Çocuğun bilişsel yetilerinin (bellek, dikkat, algılama, düşünme, öğrenme, yargılama ve değerlendirme vb.) gelişmesinde ve yetkinleşmesinde anadilini iyi bilmesinin büyük önemi vardır. Özerk birey yetiştirmek isteyen dil ve edebiyat öğretmeninin dikkat etmesi gereken önemli konulardan biri de model olarak kendisinin Türkçe sözcükleri kullanma duyarlı̆̆ının olması, bunu temel bir ilke olarak benimsemesidir. Ders ortamlarında kullandığı metinlerin Türkçenin gücünü somutlaması; inceliklerini, özelliklerini, güzelliklerini, kısaca tüm olanaklarını yansıtması gerekir. Öğretim ortamlarında Türkçe karşılıklarının olmasına karşın karma bir dilin kullanılması, özgür ve özerk olmanın önünde engel oluşturabilir. Yabancı sözcüklerin sıklıkla geçtiği metinlerin çocuklarla buluşturulması doğal olarak onlarda kendi dillerine karşı bir sevgi, duyarlık ve farkındalık yarat(a)mayacak; böylece öğrencilerde dil bilinci de oluşmayacaktır (Aslan, 2006). Yabancı sözcüklerin sıkça geçtiği metinlerin bu ortamlarda kullanılması, çocukların kullanılan dili tam olarak anlayamamalarına, bu durum da çocukların anlama ve anlatma becerilerinin gelişmemesine yol açar. Anlama ve anlatma becerileri tam olarak gelişmeyen öğrencilerse özgür ve eleştirel düşünme, kararlarını bağımsızca verebilme, kendi benliğine saygılı olma, kendi yaşamını denetleyebilme, kendi duygularına ve düşüncelerine göre hareket etme gibi özerk benlikli birey olmanın gerekleri olan nitelikleri kazanamazlar. Bilinçli ya da bilinçsiz olarak yabancı sözcük kullanma tutkusunun önüne ise okul yaşamının ilk yıllarından başlayarak özellikle dil ve edebiyat öğretimi ortamlarında yapılan etkinliklerle, kullanılan araç-gereçlerle geçilebilir.

Özerk benlikli birey yetiştirmede dili iyi bilmenin ve aynı zamanda zihinsel becerileri geliştirici çalışmaların yapılmasının ne denli önemli olduğu Türkçe Dersi Öğretim Programında da "Öğrencilerin zihinsel becerilerini geliștirme, iletişim kurma, duygu ve düşüncelerini ifade etme, bilgi edinme ve ögrrenmelerinde dilin önemli bir yeri bulunmaktadır. Dil ve zihinsel becerilerin gelişimi, öğrencilerin olayları sorgulama, çok yönlü düşünme, değerlendirme, karar verme, sosyalleşme ve çağdaşlaşma süreçlerini kolaylaştırmaktadır. Bu nedenle öğrencilerin küçük yaşlardan itibaren dil ve zihinsel becerilerini geliştirmek gerekmektedir... Günümüzde Türkçe öğretimi sadece dinleme, konuşma, okuma, yazma, görsel okuma ve görsel sunu becerilerinin geliştirilmesi değil, aynı zamanda düşünme, anlama, sıralama, sinıflama, sorgulama, ilişki kurma, eleştirme, tahmin etme, analiz-sentez yapma, değerlendirme gibi zihinsel becerilerin geliştirilmesi olarak anlaşılmaktadır. Bu durum Türkçe öğretiminde dil becerileriyle birlikte zihinsel becerilerin de geliştirilmesini ön plana çıkarmaktadır. Bunlara ek olarak iletişim kurma, öğrenme, bilinçli kararlar verme, çağdaş toplumun gereklerini yerine getirme, ögrenmeyi sürdürme gibi becerilere de ağırlı verilmektedir. Bu anlayıștan hareketle, Türkçe öğretiminde öğrencilerin hayat boyu kullanacakları bilgi ve becerileri kazanmaları beklenmektedir" (MEB Talim Terbiye Kurulu Başkanlığı, 1-5. Sınıflar Türkçe Öğretim Programı) ifadeleriyle yerini almıştır. Programla ulaşılması beklenen temel beceriler ise şunlardır: Türkçeyi doğru, güzel ve etkili kullanma, eleştirel düşünme, yaratıcı düşünme, iletişim kurma, problem çözme, araştırma, karar verme, bilgi teknolojilerini kullanma ve girişimcilik (MEB Talim Terbiye Kurulu Başkanlığı, 6, 7, 8. Sınıflar Türkçe Öğretim Programı). Yine Türk Edebiyatı dersi öğretim programında da öğretmenin öğrenme-öğretim sürecinde dikkat etmesi gereken başlıklar arasında “öğrencilerin bireysel özelliklerini dikkate almak, öğrencilerin düşüncelerini önemsemek, öğrencilerin edebî zevklerini geliştirici çalışmalar yapmak, öğrencilerin zihinsel becerilerini geliştirici çalışmalar 
yapmak, öğrencilerin, bilgilerini sınıflandırmalarına, karşılaştırma yapmalarına, bilgiler arasında ilişkilendirme kurmalarına, yeni bilgileri yorumlamalarına yardımcı olmak, öğrencilerin, kendilerini değerlendirmelerine yönelik çalışmalar yapmalarına yardımcı olmak" (MEB Talim Terbiye Kurulu Başkanlığı, 9, 10, 11 ve 12. Sınıflar Türk Edebiyatı Dersi Öğretim Programı) maddeleri sıralanmıştır.

Yabancı dille eğitim uygulaması da çocuğun/gencin özerkleşmesi önündeki önemli engellerden biridir ve bu uygulama özgürce öğrenme ve düşünebilme, iletişim kurma, öğrenmeyi öğrenme, eleştirel düşünme, problem çözme gibi çağdaş eğitimin gerektirdiği becerilerin gelişmesine engel olduğundan öğrencilerin akademik başarılarını olumsuz yönde etkileyerek kendilerine olan inançlarını ve güvenlerini yitirmelerine neden olur. Kendine olan inancını ve güvenini yitiren, başka dillerin kendi dilinden daha üstün olduğunu düşünen bir kişininse özerk benlik kimliği geliştirmesi olanaklı değildir. Oysa dil bilinci ile özerk benlik gelişimi ya da kimlik (identity) oluşumu arasında yoğun bir ilişki bulunmaktadır (Bayraktaroğlu, 2015; Karagül, 2012). Öztürk (2009a)'e göre toplumsal ve bireysel kimliği ile öz dili arasındaki bağıntıyı göremeyen, bilinçli bir dil kaygısı taşımayan "bilim insanları" gerçekte, başka dillerden ve ülkelerden sözcük ve bilgi aktarıcılı̆̆ı yapmaktan, başkalarını öykünmekten öteye gidemezler. Düşünme yetisinin gelişmesi, olgunlaşması ve açıklık kazanması ancak özerk düşünme, inceleme ve öğrenme yoluyla olur. Özgür düşünebilme, özerk benlik duygusu, yetkin kimlik ve dil bilinci gelişimsel olarak birbirinden ayrılmaz niteliktedir ve bu nitelikleri taşımayan, bilim adamı olamaz.

\section{3. Çocuk ve Gençlik Edebiyatı}

Nitelikli çocuk ve gençlik edebiyatı yapıtları, dil ve edebiyat öğretiminin bütünleyici nitelikteki en önemli araç-gereçleridir ve öğretimin amaçlarına ulaşılma sürecinde anahtar birer bileșen işlevi görürler. Etkili dil ve edebiyat öğretiminin temeli olan yazınsal nitelikli çocuk ve gençlik kitapları öğrencilere çok önemli dilsel deneyimler sunmakla kalmaz (Sever, 2008), onların düşünme becerilerini geliștirerek (Sever ve Aslan, 2009) özerk benlik duygusu geliştirmelerine de katkıda bulunur. Bu nedenle öğretmenin nitelikli çocuk ve gençlik edebiyatı yapıtlarını çeşitli dergilerden, gazete kitap eklerinden, bilgisunar sitelerinden, yayınevlerinin ağ sayfalarından, tanıtım kitapçıklarından izlemesi, okuması ve öğrencilerinin de okumalarını sağlaması gerekir. Öğretmen, bu yayınları izleyip okumazsa doğal olarak çocuk da bu yapıtlarla buluşamayacak, bireyleşme yolundaki adımları da atamayacaktır. Bireyleşmeyi önemseyen öğretmenler bu nitelikli yapıtları okutmakla kalmaz, edebiyat merkezli çalışmalara da yer verir; çünkü özerk benlik kimliğinin en iyi taşıyıcıları sanatçılardır ve sanatsal bu yapıtlar üzerine uzun soluklu çalışmalar yapmak, bu yapıtların anlam dünyalarına inmek çocukların bireyleşebilmeleri için önemli firsatlar yaratır:

"Bir toplumun bireylerinde özerk benlik duygusunu ve özgür, eleştirel düşünebilme yetisini taşıyan en güçlü kişiler özgürce yazabilen, konuşabilen yazarlar, düşünürler, sanatçılar, bilim insanlarıdır. Eski çağlardan beri düşünce özgürlüğünü en çok savunanlar, özgür düşünebilen, özerk kimlik duygusunu taşıyan sanatçılar, yazarlar, düşünürler, bilim insanları, toplum eleştirmenleri olmuştur (Öztürk, 2013:77-183).

Edebiyat merkezli çalışmalara örnek olarak, dil ve edebiyat öğretmeni edebiyat tartışma grupları kurmalı; bu ortamlarda çeşitli yapıtlardaki olaylar, durumlar, karakterler vb. üzerine düzenli olarak konuşma/tartışma ortamları yaratmalı, çocukların kitaplara yönelik sözlü tartışmalarını dinlemeli, öğrencilerin düşüncelerinin ve değerler sisteminin doğru oluşmasına yardımcı olmalıdır. Geniş metin çeşitliliği içinde çocuğun bağımsız okumalarında başarılı olup olmadığını; başka bir deyişle metinle yazınsal iletişime girip giremediğini, metnin derin yapısındaki anlamları fark edip edemediğini, metne eleştirel yaklaşıp yaklaşmadığını izlemelidir. Birey kimliğini kazanabilmesi açısından öğrencinin, edebiyat gruplarında yapılacak çalışmalara/etkinliklere katılımı çok önemlidir; çünkü bu ortamlarda öğrenci, insanı ve yaşamı eğlenerek öğrenir, kendi duygu ve düşüncelerini ortaya koyar, neleri yapma konusunda yetenekli olduğunu gösterir. Deneyimlerini artırır, yaratıcılığını geliştirir.

Örneğin, Fatih Erdoğan'ın her bakımdan başarılı bir kurgu olan “Gözü Çok Ama Çok Ağrıyan Adam" adlı çocuk kitabı, hem dersin amaçlarına ulaşılmasına hem mizahi dil kullanımıyla çocuğun eğlenerek öğrenmesine hem de çocuğun birey olmasına katkıda bulunabilecek bir içeriğe sahiptir. 
Çevre kirliliğine, gıdaların bozulmasına, GDO'lu yiyeceklerin zararlarına ve bunlara karşı neler yapılması gerektiğine ilişkin örtük iletileri olan bu kitabı öğretmen okumazsa doğal olarak çocuk da okumayacak; bireyleşme yolundaki adımları da atamayacaktır. Unutmamak gerekir ki bilgi ve deneyimleri, yazınsal birikimleri yetişkinlere göre yetersiz olsa da çocuklar estetik olanla olmayanı ayırt edebilirler. Açık iletilerle yüklü, öğreticilik yanı ağır basan, ardı arkası kesilmeyen öğütlerle dolu kitaplar yazınsal/sanatsal özleri olmadığından çocuğun birey olmasına katkı sağlayamazlar. $\mathrm{Bu}$ tür metinler kendi doğrularını dayatmaya çalışmaktan ileriye gidemezler; etkileri de elbette anlık ve yüzeysel olur, kalıcı bir iz bırakamaz. Aslan'a (2014) göre, yazınsal çocuk ve gençlik kitaplarında da yetişkin edebiyatında olduğu gibi yazarın öncelikli kaygısı, çocuğa/gence görelik ilkesine uygun sanatsal değeri olan bir ürün ortaya çıkarmak olmalıdır; çocuklara belli ahlaki değerleri ya da düşünce anlayışını belletmek değil. Başka bir deyişle; ideolojisini çocuğu belli bir politik ya da dinsel anlayışa güdümlemeye çalışacak, onda eyleme dönük duygular oluşturacak, çocuğa bir dünya görüşünü politik bir söylemle dayatacak biçimde ortaya koymamalıdır. Kitap, çocuğu belli bir ideolojiye yöneltme amacını gütmeden, yazarının anlayışına uygun biçimlendirmeye çalışmadan evrensel bir değerin, insani bir duyarlığın peşinde olmalıdır. Çocuğa nasıl davranması gerektiğini öğreten, ahlaksal öğütler veren kitaplar çocuğun/gencin bireyleşme sürecine; bașka bir deyișle, bağımsız kișiliğe varan gelișme sürecine ket vurur.

Çocuklara ve gençlere önerilecek yazınsal kitaplar, alan uzmanlarının önerileriyle ve bilimsel ölçütler ışığında belirlenmelidir. Kitapların laik, demokratik ve bilimsel eğitime katkı sağlayacak nitelikte olup olmadığı, şiddetin ve ayrımcılığın olağan bir durummuş gibi gösterilip gösterilmediği, belli bir ideolojiyi dayatıp dayatmadığı da titizlikle sorgulanmalıdır. Belli bir kesimin duygusu, düşüncesi, inancı ve ideolojisi çocuğa dayatılmaya çalışılmamalıdır. Unutulmamalıdır ki çocuk gerçekliğinin yansıtılmadığı, çocuklarla iletişime giremeyen, ona kendi inancına ve düşüncesine dayanak olan ilkeleri dayatmacı bir yaklaşımla aktaran kitapları çocuklara okutmaya kalkışmak, çocuğun birey olmasının önündeki en önemli engellerdendir. Edebiyat, amacı/kaygısı bu olmamakla birlikte çocuklara da yetişkinlere de bir şeyler öğretir, okurlarını örtük bir estetik eğitimden geçirir (Kavcar, 1999; Sever ve Aslan, 2009); ancak temel ve baskın kaygı "öğretmek/dayatmak" olursa bu zaten edebiyat olmaz ve okur da kitapla sanatsal bir etkileşime giremediği için bireyleşme sürecini tamamlayamaz. Yine çocuklara/gençlere okuma alışkanlığını kazandırabilmek amacıyla düzenlenen kitap okuma projelerinde de aynı şekilde alan uzmanlarının bilgi ve önerilerinden yararlanılmalıdır.

Özetle söylemek gerekirse, etkili dil ve edebiyat öğretiminin temeli ve vazgeçilemez tamamlayıcı araçları olan yazınsal nitelikli çocuk ve gençlik edebiyatı kitapları, öğrencilerin bireyleşme sürecine önemli katkılar sunar. Dil ve edebiyat öğretmenleri çocukların edebiyat yapıtlarını okumaya yaşam boyu ilgi duymaları, bunu bir gereksinim olarak duyumsamaları için edebiyat merkezli çalıșmalara etkili biçimde yer vermelidir. Bu tür çalışmalar, bir yandan dersin amaçlarını gerçekleştirirken bir yandan da çocukların eğlenerek ve duyumsayarak doğru değerler oluşturmalarına, özgürleşmelerine ve bireyleşmelerine katkıda bulunur. O halde çocuklar, dil ve edebiyat öğretimi ortamlarında bir anlayışı ya da yetişkin ideolojisini edebiyat yoluyla belletmeye çalışan, çocuğun/gencin gerçeklerinden uzak ve siyasal öğretilerin bilinçli ve amaçlı bir biçimde verilmeye çalışıldığı kitaplarla buluşturulmamalıdır. Kısaca, çocuğun/gencin özerk birey olması isteniyorsa çocuk kitapları, yazarın aşılamak istediği dünya görüşünün benimsetilmesine hizmet eden bir araca dönüștürülmemelidir. Çocuklara okuma alıșkanlığını kazandırmak amacıyla çeșitli listelerin oluşturulması ve bunların çocuklarla buluşturulması yaklaşımı yalnızca doğru kitapların, doğru ve bilimsel kaynaklarca seçilmesi durumunda yararlı olabilir. Bunun yolu da alanla ilgilenen uzmanların, öğretmenlerin ve bilim insanlarının görüş, düşünce ve önerilerinin alınmasından geçer.

\subsection{Sorular Nasıl Olmalıdır?}

Dil ve edebiyat öğretimi ortamlarında bireylerin yetişmesine katkıda bulunacak önemli araçlardan biri, öğretmenlerin gerek sınıf içi değerlendirme etkinlikleri çerçevesinde gerekse sınavlarda kullandıkları sorulardır. Düşünme, sorgulama, özgürleşme eylemlerinin bir sonucu olan bireyleşme süreci; verimli, işlevsel, öğretimin amaçlarına uygun soruların sorulmasıyla ve bunların yanıtlanması çabalarıyla başlar. Ancak etkili ve nitelikli sorular öğrenciyi düşünsel bir çaba içine sokar, onun bağımsız kararlar alabilmesine, yanıtlarını özgürce oluşturabilmesine, kendi duygu ve 
düşüncesini yansıtmasına; aslında kendini ortaya koyarak bireyleşmesine katkıda bulunur. Öğretmen öğrencilerine zorlayıcı, düşünmeye yönelten, yanıtı tek doğru gerektirmeyen açık uçlu sorular sormalı; soruların yanıtlarını ise yeterli kanıt ya da gerekçelerle desteklemelerini ve bulgulara dayalı sunmalarını istemelidir. Sorular, öncelikle konunun/metnin öğrencilerce anlaşılmasını sağlamalıdır. Konunun/metnin anlaşılmasından sonra ise öğrencileri metindeki olaylar üzerine konuşturacak, tartışmalarını, düşünmelerini, metnin derin yapısındaki anlamları/iletileri bulmalarını, derin yapıdaki anlamları keşfetmelerini, metni etkin biçimde yeniden üretmelerini sağlayacak sorular sorulmalıdır (Aslan, 2010 ve 2011a).

Ülper ve Yalınkılıç'a (2010) göre, öğrencilerin metne ilişkin soruları doğru yanıtlayabilmelerinde ve o sorulardan bilişsel gelişim açısından yararlanabilmelerinde soruların taşıdığı nitelikler önemli bir yere sahiptir. Sorular, bilimsel ilkeler doğrultusunda ve alanında uzman kişilerce hazırlandıysa hem öğrencilerin metni anlayıp anlamadıklarına ilişkin sağlıklı bir biçimde saptama yapılabilmesine hem de öğrencilerin derin metni anlayabilmelerine ve artalan bilgisi oluşturarak metni değerlendirebilmelerine hizmet ederek bilişsel gelişim düzeylerinin yükselmesine katkı sağlar.

Dil ve edebiyat öğretimi ortamlarında anlatılan konular ve sorulan sorular çocuğun varoluşsal deneyimine yabancı olmamall; öğrenci ezberlemek zorunda kalmadan bilginin ne ișe yaradığını öğrenmeli ve bilgi üzerine düşünmeli ki onun "bütün" içindeki anlamına, işlevine, amacına, önemine ulaşabilsin ve böylece bireyleşme sürecini tamamlayabilsin. Eğitim; ezberletip unutturucu değil, her etkinliğiyle değiștirip dönüștürücü olmalıdır. Günümüzün yaşayan en önemli düşün adamlarından Morin (2013:X)'in de eğitimde gördüğü en önemli eksiklik budur: öğrencilerin bilmenin ne olduğu üzerinde düşündürülmemesi, onlara yalnızca birçok bilginin aktarılmasıyla yetinilmesi.

Özetle söylemek gerekirse, dil ve edebiyat öğretimi ortamlarında öğrencilere metni anlamaya/kavramaya dönük soruların yanı sıra onların yaratıcllıklarını, kestirimde/çıkarımda bulunma, eleştirme, değerlendirme, sorun çözme ve karar verme gibi bireyleşmeye katkı sağlayacak becerileri geliştirecek soruların da sorulması önemli ve gereklidir.

\subsection{Etkinlikler Nasıl Olmalıdır?}

Dil ve edebiyat öğretimi ortamlarında yapılması tasarlanan etkinlikler de dersin amaçlarına ulaşılmasını sağlayacak nitelikte ve işlevsel olmalıdır. Öğretmen, öğrencilerini gerçek yaşam durumları üzerine düşündüren, derste öğrendiklerini yaşama aktarmalarına olanak tanıyan etkinlikler düzenlemelidir. Her türlü metnin en başarılı örneklerini okutmak ve bunları eleştirel olarak çözümletmek; çocukları bu metinlerdeki olaylar, sorunlar ve karakterler üzerinde özgün düşünceler üretmeye yöneltmek, öğrencilerin dille doğal bir biçimde oynamalarını sağlayacak, düşüncelerini eyleme geçirmelerini cesaretlendirecek, yaşamda farklı düşünce ve anlayışlar olduğunu sezdirecek etkinlikler yaptırmak, metinlerdeki karakterlere mektuplar yazdırmak, öğrencilerin merak duymalarını ve araştırma yapmalarını destekleyen ortamlar yaratmak, onlara dilsel gelişmelerini duyumsatmak, öğretim ortamını; savaşlar, insan hakları ihlalleri, çevre sorunları, adaletsizlikler vb. konularda öğrencilerin duyarlı olmalarını sağlayacak sanatsal olanaklarla donatmak çocukların algılarını ve özerk benlik duygularını geliştirici etkinliklerdendir.

\section{6. Öğretimde Kullanılan Araç-Gereçler (Materyal) Nasıl Olmalıdır?}

Dil ve edebiyat öğretimi ortamlarında kullanılan araç-gereçlerin (edebiyat yapıtları, bilimsel ve sanatsal dergiler, uzun metrajlı filmler, kısa filmler, karikatür, resim, heykel, tablolar, videolar ve diğer sanatsal olanaklar vb.) niteliği çok önemlidir ve bunların hem öğretimin amaçlarına hem de çocuğun/gencin yaş ve gelişim özelliklerine, ilgi ve beğenilerine uygun olarak titizlikle seçilmesi gerekir. Anılan ortamlarda öğrencilerin görme ve işitme duyularına seslenen araç-gereçlerin kullanılması bir gerekliliktir ve bu durum öğretmenin teknolojiden (bilgisayar, bilgisunar vb.) etkili biçimde yararlanabilmesini gerektirir. Başka bir deyişle öğretmen, teknolojik olanaklarla desteklenmiş etkili bir sınıf ortamı tasarlamalı; yeri geldiğinde öğrencilere işlediği metnin konusuyla koşut bir kısa ya da uzun film izletebilmelidir. Örneğin, okunan bir romanın sinemaya uyarlanmış biçimini sınıfta izletip kitapla film arasındaki benzerlik ve benzemezlikleri, çelişkileri, 
koşutlukları bulmalarını; filmin zayıf ya da güçlü yanları üzerine konuşmalarını sağlayacak etkinlikler yoluyla öğrencilerin özerk bireyler olmalarına katkıda bulunabilir.

Bir sorunu, bir durumu fazlaca ayrıntıya ve yan öykülere girmeden, kısa sürede, çarpıcı ve zekice anlatan, yaratıcı, yalın ama yoğun, ders verme çabasına girmeyen, özgür ve özgün, basmakalıp simgeler kullanmamaya çalışan, sanatsal bir dil kullanan kısa filmler de çocukların/gençlerin özerkleşebilmeleri açısından dil ve edebiyat öğretimi ortamlarında etkili bir biçimde kullanılmalıdır (Aslan, 2011b).

Dil ve edebiyat öğretiminde mizahi öğelerin kullanılması da özerk bireylerin yetiştirilmesine önemli katkılar sağlar. Dil ve edebiyat öğretmenleri; sınıfların kalabalık oluşu, öğretim programındaki konuları yetiştirememe kaygısı, çocukları çeşitli sınavlara hazırlama çabaları, öğrencilerin bireysel farklılıkları ve duyarlıkları, ailelerinin eğitim ve sosyoekonomik durumları gibi nedenlerle derslerinde mizaha yer vermek istemeyebilirler. Ancak mizahi öğeler, öğrencinin dersin içeriğine daha iyi odaklanmasını, dersi daha dikkatli dinlemesini ve doğal olarak daha iyi ve keyifli öğrenmesini; başka bir deyişle öğrenmeye güdülenmesini, ayrıca gerginlik yaşamadan öğrenmenin işe koşulması nedeniyle konunun daha kalıcı olmasını sağlar. Kendisi bir yaratıcılık olan mizah; etkili, yerinde, dersin içeriğine, çocuğun yaş ve gelişim düzeyine uygun kullanıldığı durumda dersin amaçlarına ulaşılmasını, öğrencilerin farklı ve yeni düşünme yollarını görmelerini sağlayan, öğrencilerin yaratıcıllğını besleyen, özgüvenlerini ve özsaygılarını geliştiren önemli bir araçtır. Özetle söylemek gerekirse dil ve edebiyat öğretimi ortamlarında konunun hem daha iyi ve kalıcı hem daha eğlenceli öğrenilebilmesi hem de öğrencilerin özerkleșebilmesi için öğretimin amaçlarına, işlenen konunun içeriğine, öğrencilerin yaş ve gelişim düzeylerine uygun mizah öğelerinden yararlanılmalıdır. Elbette bu da öğretmenin bu tür mizahi yapıtları bilmesini, izlemesini, okumasını; kısaca bunlardan haberdar olmasını ve derse girmeden önce ilgili ve uygun olanları hazırlamasını gerektirir.

\subsection{Dilbilgisi Öğretimi Nasıl Yapılmalıdır?}

Dilbilgisi, "Bir dilin seslerini, sözcük türlerini, bunların yapılarını, tümce olarak dizilmelerini ve tümce içindeki görevlerini, çekimleriyle ilgili kurallarını inceleyen bir dilbilimi dalı"dır (Göğüş, 1978). Dilbilgisi konu alanı; sesler, sözcük türleri ve sözcük yapıları, sözcüklerin tümce olarak dizilmeleri, sözcüklerin tümce içindeki görevleri ve çekimleri ile ilgili kuralları inceler. Dilin diğer etkinlik alanlarının; başka bir deyişle anlama ve anlatma becerilerinin doğru ve etkili kullanılmasına yardımcı olur. Türkçe öğretiminde belirlenen amaçlara anlama ve anlatma etkinlikleriyle ulaşılmaya çalışılır; ancak bu etkinlikler "yazım", "noktalama", "sözcük bilgisi", "cümle bilgisi", "doğru söyleyiș" gibi bilgi ve beceri kazandırmaya yönelik uygulamalarla desteklenmelidir. Dilbilgisi çalışmaları ayrı bir ders ya da etkinlik alanı gibi görülmemeli, temel dil becerileri ile bütünleşik olarak anlama ve anlatma etkinlikleri içerisinde yer almalıdır (Sever, Kaya ve Aslan, 2008). Dilin yapısını ve olanaklarını bilmek, anlama ve anlatma becerilerinin gelişimini de etkiler. Dil, değerlerini birbirleriyle olan ilişkilerinden alan birimlerin oluşturduğu bir dizge, dilbilgisi de bu dizgeyi ortaya koymayı, dizgeyi oluşturan kuralları bulmayı, bunları tutarlı bir biçimde açıklamayı amaçlayan çalışma alanıdır. Bireyler ancak anadilinin yapısını ve olanaklarını bildiklerinde açık, etkili ve sağlıklı iletişim kurabilirler. Dilbilgisi öğretiminde asıl amaç, çocuğun içinde yaşadığı dili kavratmaktır (Adalı, 1983).

Dilbilgisi öğretiminin ezbere, metinden ve bağlamdan kopuk, kurallar yığını biçiminde yapılığı, uygulamalarla pekiştirilmediği bilinen bir gerçektir (Şimşek, 1997; Sağır, 2002; Özbay, 2006; Karadüz, 2007; Sever, Kaya ve Aslan, 2008; Erdem ve Çelik, 2011; Temizkan, 2012). Bu durumda dilbilgisi öğretiminde öncelikle öğretilecek konuya uygun nitelikli metinlerin seçilmesi çok önemlidir. Dilbilgisel konular (önad, adıl, belirteç, eylemsiler), o konuya ilişkin kuru bilgiler biçiminde anlatılmamalı; yaklaşım, kuralı derste işlenen metindeki örnekler yoluyla sezdirmek, anlama ve tanıma öğrencinin ulaşmasını sağlamak olmalıdır. Konu, tümce içinde ele alınmalı ve bağlam içinde değerlendirilmelidir. Öğretimde, öğrencilerin sıklıkla yaptıkları yanlışlar ve karşılaştıkları dilsel sorunlar çıkış noktası olmalı ve bu sorunların giderilmesi için çok sayıda alıştırma yapılmalıdır. Dil ve edebiyat öğretimi ortamları özgün kişiliklerin, bireylerin yetişmesi için çocuğun düşünsel gelişimini, insani yetkinleşmesini destekleyecek, içinde var olan olanaklarını ortaya çıkarmasını sağlayacak bir anlayışla yapılmalıdır. Çocuk; öğretime kendi öznelliğiyle, 
özgünlüğüyle, istek ve edimleriyle katılmalıdır. Dilbilgisi dersleri çocukların ilgi duyacakları her tür metinle desteklenerek ilgi çekici ve eğlenceli biçime dönüştürülmelidir. Hoşgörülü, demokrat, kendisiyle ve kendi değerleriyle barışı özgür bireylerin yetiştirilmesinde çok önemli bir yeri olan karikatür sanatının derse uygun ürünleri dilbilgisi öğretiminde de yararlanılabilecek önemli araçlardandır.

Dilbilgisi öğretiminde dikkat edilmesi gereken bir diğer konu da anlatımında önadı, adılı, belirteci, eylemsileri zaten kullanan öğrencinin bu konuları neden daha ayrıntılı öğrenmesi gerektiğini bilmesidir. Dilbilgisel konuların yalnızca bilgi aktarması biçiminde yapılması durumunda -aynı konu defalarca anlatılsa bile- aktarılan bilgiler kalıcı ve işlevsel olmaz; kısa bir süreliğine öğrenilip sonra yeniden unutulur. Çocuğun her konuya olduğu gibi dilbilgisel konu alanına da eleștirel bakması, öğrenmeyi sorgulaması ve bu konuyu öğrenmenin kendisine ne gibi katkılar sağlayacağını bilmesi gerekir. Örneğin eylemsiler, daha karmaşık olduğu gerekçesiyle ilk kez ortaokul 4. sınıfta anlatılmaktadır. Öğretimin amacına ulaşılabilmesi; bașka bir deyişle, öğrencinin; eylemsileri doğru, yerinde ve işlevsel olarak kullanabilmesi için öncelikle eylemsilerin sıkça ve etkili kullanıldığı, bununla birlikte çocuğun yaş ve gelişim düzeyine uygun nitelikli bir metnin seçilmesi ön koşuldur. Metnin okunup anlaşılmasına dönük çalışmaların yapılmasından sonra öğretmenin, öğrencilerin dikkatlerini metin içindeki fiilimsilere çekmesi, öğrencileri bu yapıların metne neler kattığı, ne gibi işlevler üstlendiği üzerine düşündürmesi gerekir. Eylemsilerin ne işe yaradığı öğretmen eşliğinde ve öğretmenin verdiği ipuçlarıyla tartışıldıktan sonra metinden eylemsilerin kaldırıldığı durumda olabilecek/karşılaşılabilecek sorunlar örnekler yoluyla gösterilmelidir. Tüm bu çalışmalar sonucunda eylemsilerin önemi ve işlevi, iyi öğrenildiği durumda anlama ve anlatma becerilerine olabilecek katkıları çocuklarla birlikte ortaya konmalı ve "Eylemsiler iyi öğrenildiği durumda daha uzun, daha güzel, daha sanatsal cümleler kurulabilir. Gereksiz sözcük yinelemeleri yapılmaz." türünden kurallara ulaşılmalıdır. Konu, nitelikli başka metinler üzerinde yürütülen ek çalışmalarla pekiştirilmelidir.

Özetle söylemek gerekirse; konunun ayrıntılı bilgiler/kurallar eşliğinde, metinden ve bağlamdan kopuk örneklerle anlatılmasının çocuğun öğrenmesine ve öğrendiği konuyu işlevsel biçimde kullanmasına çok fazla katkısı olamaz. Bu durumda dilbilgisel konuların öğretiminde öğretmen, kurala öğrencinin ulaşmasını sağlayacak çalışmalar yaptırmalı, öğrenciyi öğreneceği konunun önemine ve gerekliliğine ikna etmeli, çocuğun bunları bilmesinin onun anlama ve anlatma becerilerine ne gibi katkılar sağlayacağını açıklamalıdır. Kısaca dilbilgisi öğretimi, dilin kurallarının öğrenilmesi gerekliliğini gerekçeleriyle ortaya koyacak biçimde yapılmalıdır. Birey yetiştirme amacı olan dil ve edebiyat öğretmeni, eğitimi yalnızca işlevi olmayan uygulamalara ve çocuğun ezber yapmasını gerektiren çoktan seçmeli sınavlara indirgememelidir. Birey yetiştirmek isteniyorsa dil ve edebiyat öğretiminin her alanının olduğu gibi dilbilgisi öğretiminin de yaratıcı, düşündürücü, dönüştürücü ve üretken olması gerekir. Bilginin günlük yaşamında ne işe yarayacağı, ona neler sağlayacağı çocuğun bilmesi gereken bir konudur. Yığma bilgileri, edilgin biçimde dinleyen çocuğa aktarmanın çocuğun özerk birey olmasına hiçbir katkısı yoktur.

\section{8. Öğretimde Kullanılan Yöntem ve Teknikler Nasıl Olmalıdır?}

Dil ve edebiyat dersleri, dersin çağdaş öğrenme-öğretme yaklaşımlarına uygun yapılandırılması durumunda birey yetiştirmek için en ayrıcalıklı derslerden biridir. Öğretim beceri kazandırmaya dönük yapılmalı, bu amaçla yeri geldiğinde uygun yöntem ve teknikler kullanılmalıdır. Bilinen ve sıklıkla uygulanan birkaç yönteme bağlı kalınmamalı, yöntem zenginliği ve çeşitlilik ilkesi benimsenmelidir. Öğretimin amacına ulaşılabilmesi için öğrencinin derse etkin katılımı çok önemlidir. Bu nedenle öğretmen, öğrencinin etkin olarak derse katıldığı, kendini gerçekleștirdiği, kendi duygu ve düşüncelerini, tasarılarını paylaşmasına olanak sağlayan etkinliklerin gerçekleştirilmesine hizmet edecek yöntem ve teknikler kullanmalıdır (Strickland, Galda ve Cullinan, 2004; Aslan, 2010a). Paulo Freire (1995:50-51) eğitimin anlatım hastalığını "Bankacı Eğitim" olarak adlandırır ve bu sistemi şu cümlelerle anlatır:

"Öğretmen gerçeklikten sanki kıpırtısız, durağan, ayrı bölümlerden oluşan ve öngörülebilir bir şey gibi söz eder. Ya da öğrencilerin varoluşsal deneyimine tamamen yabancı bir konuda uzun uzadıya açıklamalar yapar. Görevi öğrencileri anlatısının 
içindekilerle -gerçeklikten koparılmış, onları ortaya çıkarmış olan ve anlam kazandırabilecek bütünlükle bağlantısı koparılmış içeriklerle- "doldurmak"tır... O halde anlatıcı eğitimin başlıca özelliği sözcüklerin tınısıdır, dönüștürücü gücü değil. 'Dört kere dört on altı eder; Para'nın başkenti Belem'dir.' Öğrenci dört kere dördün gerçeklikte ne olduğunu algılamadan veya "Para'nın başkenti Belem'dir" önermesindeki "başkent"in gerçek anlamını yani Belem'in Para için ve Para'nın Brezilya için anlamını kavramaksızın bu ibareleri ezberler ve tekrarlar. Anlatı (öğretmenin anlatıcı oluşuyla) öğrencilerin, anlatılan şeyi mekanik olarak ezberlemelerine yol açar. Daha beteri, onları öğretmen tarafından doldurulması gereken "bidonlar"a, "kaplar"a dönüştürmesidir. Öğretmen kapları ne kadar çok doldurursa o kadar iyi bir öğretmendir. Kaplar ne kadar pısırıksa, doldurulmalarına izin veriyorsa o kadar iyi öğrencidir. Böylelikle eğitim bir "tasarruf yatırımı" edimi haline gelir. Öğrenciler "yatırım nesneleri", öğretmen ise "yatırımcı"dır. Öğretmen iletişim kurmak yerine tahviller çıkarır ve öğrencilerin sabırla aldığı, ezberlediği ve tekrarladığı yatırımlar yapar. Bu, ögrencilere tanınan hareket alanının, yatırılanı kabul ve tasnif edip yığmaktan ibaret olduğu "bankacı" eğitim modelidir. Gerçi öğrenciler, bilgilerin koleksiyoncusu veya arşivcileri haline gelme, onları raflara dizme firsatına sahiptirler. Fakat son tahlilde bu (en iyi deyimle) yanlış yoldaki sistemde, yaratıcılık, dönüşüm ve bilgi yoksunluğu yüzünden "rafa kaldırılan" bizzat insanlardır. Çünkü kendileri araștırmadan, praksis olmaksızın, insanlar hakikaten insani olamazlar. Bilgi ancak ve ancak, buluş ve yeniden -buluş- yoluyla, dünya içindeki, dünya ile ve birbirleriyle olan insanların sabırsız, durmak bilmeyen, sürekli, umut dolu araştırmalarıla peșinden koșmalarıla meydana gelir.

\subsection{Yazılı Anlatım Çalışmaları Nasıl Yapılmalıdır?}

Eleştirel düşünmenin en temel bileșeni olan yazılı anlatım becerisi, diğer becerilere göre daha uzun zamanda ve zor gelişen bir beceridir. Dil ve edebiyat öğretiminde öğrencinin ilgisine, beğenisine, gereksinimine, yaş ve gelişim düzeyine uygun seçenekli konularda duygu ve düşüncelerini yazma çalışmaları çocuğun bireyleşmesine önemli katkılar sağlar. Çocuğa öncelikle bir yazı planının nasıl yapılması gerektiği öğretilmeli; ders ortamlarında sık sık yazma çalışmaları yapılmalıdır. Öğrencilerin, yazılarına kendi doğrularını koyup koymadıkları, duygularını ve düşüncelerini özgürce, özgün örnek ve gerekçelerle savunup savunamadıkları gözetilmeli ve olumlanmalı; bunları yapmaları gerektiği konusunda cesaretlendirilmelidir. Süreç temelli yazma eğitimi yaklaşımının gerekleri yerine getirilmeli; öğrencileri konuya yakınlaştırma, onların konuyu sınırlandırmalarına ve yazı planlarını oluşturmalarına yardım etme, öğrencilerin düşüncelerini düzenleme, öğrencilere dönüt verme ve yanlışlarını düzeltme, öğrencileri izleme ve değerlendirme gibi süreçler iyi yönetilmelidir (Tabak ve Göçer, 2013).

Bugün bile hâlâ dil ve edebiyat öğretimi ortamlarında kompozisyon sorusu olarak "Sakla samanı gelir zamanı", "Damlaya damlaya göl olur", "Bana dokunmayan yılan bin yaşasın”, "Bal tutan parmağını yalar." gibi atasözlerinin açıklanması istenmektedir. Bu atasözlerinin dilimizin sözvarlığı öğeleri olarak bize ne iletmek istediklerinin öğretilmesi/açıklanması da gerekir; ancak beklenti atalarımızın yıllarca önce söyledikleri bu sözlerin iletilerini öğrenciye yeniden onaylatmak, bunun mutlak doğruluğunu yazmalarını istemek olmamalıdır. Öğretmen, öğrencilerinden bu tür atasözlerini açıklamalarını istiyorsa bile bunları kendi doğrularına göre, kendi gerekçe ve örnekleriyle değerlendirmelerini, kendi düşünceleriyle geliştirmelerini istediğini belirtmelidir. Çocuk, bir atasözünü açıklarken kendi yaşantısını, kendi duygularını ve düşüncelerini ortaya koyma konusunda yüreklendirilmeli; öğrenciler, kendilerini bu atasözlerinin iletilerini benimsemek zorunda hissetmemelidir. Dayatmanın olduğu yerde “özerk birey"in yetișmesi pek olası görünmemekte, şansa kalmaktadır. Bir doğruyu dayatmaya çalışmak her şeye boyun eğen bir toplum yaratma yolunda bir adım olabilir ve bu durum da toplumun kendisi için tehlikelidir. Çocukların öğrenmesini ve birey olmasını teşvik eden sınıf ortamının duygusal olarak güvenli, demokratik, destekleyici ve özgür olması gerekir. Özetle söylemek gerekirse, dil ve edebiyat öğretimi ortamlarında sorulan sorulara öğretmenin beklentisine uygun yanıtlar verilmesi beklenirse demokrasinin önemi konusunda söylenenler içtenliksiz ve kuru sözlerden öteye gitmeyecektir. Öğrencilerin ürettikleri metinler yalnızca dilbilgisi kurallarına uygunluk, noktalama 
imlerinin doğru kullanılması, kâğıt düzeni, yazının okunaklı oluşu gibi ölçütlere göre değerlendirildiğinde öğrenci duygu ve düşüncelerini özgür ve özgün biçimde aktarmaktan çok anılan ölçütlere odaklanmaktadır. Bu ölçütler elbette çok önemlidir; ancak yazma eylemini yalnızca bu ölçütleri önemseyerek gerçekleştirmenin çocuğun/gencin yazılı anlatım çalışmalarına severek ve istekle katılmalarına, duygu ve düşüncelerini aktarmaya odaklanamadıkları için de özerkleşmelerine katkısı olamaz.

\subsection{Farklı Sanatların Olanakları Nasıl Kullanılmalıdır?}

Kişilerin duygularını ve düşüncelerini eğitmeyi amaçlayan dil ve edebiyat öğretimi ortamlarında, yeri geldikçe farklı sanatların olanaklarının etkili bir biçimde işe koşulması gerekir. Sever'e (2002) göre, görsel sanatların sunduğu olanaklar, öğrencilerin anlama sürecinde görme duyularını da ișe koşmalarına, çok boyutlu düșünmelerine, metinlerin iletilerine düşsel ve düşünsel katkılar getirmelerine, görsel ve duyu algılarını geliștirmelerine uygun ortamlar yaratır. İnsanın kültürel gelişiminde etkili olan bir yaşantı alanıdır. İpşiroğlu'na (2000) göre, bir resmi tüm özellikleriyle alımlayan biri, okuduğu yazınsal metne de çok farklı yaklaşacaktır. Duyularla düşünmenin bütünleştiği bir bakışla dikkatini yapıtın dili, kurgusu, kompozisyonu, kısaca kullanılan malzemenin yoğruluşu üzerinde odaklaştırarak yapıtın özünü çlkarabilecektir. Yazınsal bir metni okuduktan sonra bütüncül bir bakışla yapıtın özünü, izleklerini ve iletilerini çıkarmak gerekir. Duyu algılarıyla düşünme yetisi gelişmeyenlerin bunları yapması zordur. Bu durumda öğrenci yalnızca anlatılan olaylar zincirine bağlı kalacak, olaylar arasındaki bağlantıları kavrayamayacaktır.

Kagan'a (1993) göre, insanı eğitmenin en etkili araçlarından biri olarak sanat, insanın somut yaşamı içinde duyup yaşayamayacağı şeyleri duyup yaşamasını sağlar. Sanat yapıtı, hem düşünceye hem de duyguya yönelir; yalnız kendi anlayış gücümüzle değil, kendi psişik güçlerimizin tüm canlı birliği içinde, bütün belleğimizle gerçek yaşamı algılama biçimimize bizden hem bir anlayış gücü hem de bir yaşantı bekler. Kişi ancak sanat yapıtının kendisiyle buluşarak, doğrudan bir deneyim sonucu, sanatsal etkinliklere katılıp bu yapıtlarla etkileşime girerek sanatsal gizilgücünü biçimlendirir ve sanatsal beğenisinin oluşmasına katkı sağlar. Kişinin sanatsal potansiyelinin oluşması ve gelişmesi yalnızca kendisi için değil, tüm toplum için önemlidir.

Dil ve edebiyat öğretimi ortamlarında, çocukların/gençlerin duygularını ve düşüncelerini eğitecek, onların kültürel yönden gelişmelerini sağlayacak, entelektüel bağımsızlıklarını besleyecek çalışmalar yapılmalıdır. Bu ortamlarda her türden metinle farklı sanatların olanaklarını birlikte ve etkilice işe koşmak öğrencilerin yaratıcılıklarını geliștirir, bakıș açılarını geliştirerek bireyleşmelerine katkı sağlar. Çocuğun estetik yargısının gelişmesi, geçirdiği estetik uyaranlarla buluşma sıklığına bağlıdır. Bu nedenle görsel sanatların olanaklarının, özellikle dil ve edebiyat öğretimi ortamlarında ve ders kitaplarında ağırlıklı olarak yer alması gerekmektedir. Ders ortamları çocuklara bu yaşantıları sunarak çocukların estetik yargısının oluşmasına/gelişmesine katkıda bulunmalıdır.

\subsection{Ders Kitapları ve Öğretim Programı Nasıl Olmalıdır?}

Bir sanat eğitimi süreci olan dil ve edebiyat öğretiminde, dersin amacına uygun bilimsel ve sanatsal uyaranların yanı sıra bir eğitim aracı olarak ders kitaplarından da yararlanılabilir. Ders kitaplarına alınan metinler, çocukların duygu ve düşünce dünyalarını geliştirecek, değişip dönüşmelerine katkı sağlayacak nitelikte olmalıdır. Metinleri anlamaya dönük sorular genelgeçer ve yinelemeye dönük yargıları içermemeli; öğrencinin konuya farklı açllardan bakabilmesini sağlamalıdır. Kitapların çocuklara aynı zamanda sanat eğitimi verebilmesi için dış yapı ve görsel tasarım ilkeleri açısından da özenle hazırlanması gerekir. $\mathrm{Bu}$ da sanat eğitimi sürecini tamamlamada önemli sorumluluk üstlenen karikatür, resim, fotoğraf, sanatçı portreleri, minyatür, animasyon, heykel ve grafiksel tasarım, tiyatro oyunlarından fotoğraflar, sinema afişleri gibi diğer görsel sanatların olanaklarının kitaplara amaca uygun biçimde alınmasıyla olanaklıdır; çünkü görsel sanatların sunmuş olduğu bu olanaklar, çocuklarda estetik duyarlığın oluşmasına/gelişmesine, öğrencilerin anlamasına yardımcı olarak onların çok boyutlu düşünmelerini sağlar. Metinler, çocukların sanatsal ve estetik gelişim evrelerine uygun resimlerle ve diğer sanatların olanaklarıyla desteklenmeli; kitapların kapak ve sayfa tasarım özellikleri, öğrencilerin görsel algılarının gelişimine katkı sağlayacak nitelikte olmalıdır (Aslan, 2010b). 
Ders kitaplarına alınan görseller; metinlerin içeriğine, yazılış dönemine ilişkin dönütler sunmalı, estetik özellikler taşımalıdır. Diğer sanatların olanaklarını öğrenciyle amaca hizmet edecek biçimde buluşturabilmesi, renklerin ve çözünürlüğün iyi olabilmesi için bu kitaplarda kuşe kağıt kullanılmalı; yazarların ve sanatçıların sanat değeri yüksek yapıtları alınmalıdır. Bu yolla çocuklar hem çağdaş sanatçılarımızı tanıyacak hem de onların sanat eğitimi plastik yoldan desteklenmiş olacaktır (Erkmen, 1996).

Ders kitapları çocuklara estetik yaşantılar sunarak çocukların estetik yargısının oluşmasına/gelişmesine katkıda bulunmalıdır. Oysa Türkiye'de Türkçe/Türk Dili ve Edebiyatı ders kitapları üzerine yapılan çalışmaların çoğu kitapların dış yapı tasarım özellikleri (İşeri, 2003; Yazar, 2003; İçmeli, 1996; Coşkun, 1996; Durak, 1998; Güngör, 1998; Kuntay, 1998; Durmuşçelebi, 2007) bakımından da çoğunlukla amaca uygun hazırlanmadığını ortaya çıkarmıştır. Aslan'ın (2010b) "Türk Edebiyatı" ders kitapları ile "Fransız Edebiyatı" ders kitaplarını dış yapı özellikleri ve görsel tasarım öğelerine yer verme düzeyi bakımından incelediği çalışmasının sonuçları Türk Edebiyatı ders kitaplarının hem dış yapı özellikleri hem de görsel öğelere yer verme düzeyi bakımından beklenen nitelikte olmadığını göstermiştir.

Dil ve edebiyat öğretimi ders programları da en bașta yaşanan ülkenin gerçeklerine ve kültürüne uygun, öğrencilerin gerçek gereksinimlerine yanıt verecek biçimde ve alan uzmanlarınca hazırlanmalıdır. Programlar ya da programlarda yapılan yenilikler/değişimler, ön çalışma (pilot) sonuçlarının başarılı olması durumunda uygulamaya konulmalıdır.

\subsection{Nasıl Ödevler Verilmeli ve Değerlendirmede Nelere Dikkat Edilmelidir?}

Etkili dil ve edebiyat öğretmenleri birey yetiştirmek istiyorlarsa öğrencinin etkin olarak kendisinin yapabileceği (işin içinde kendisinin bulunacağı), öğretimin ve dersin amaçlarını gerçekleștirmeye hizmet edecek (doğrudan öğretimin amacına dönük, öğretimle bağlantılı), öğrencinin düzeyine uygun işlevsel ve özgün ödevler hazırlamalı; bu ödevleri, verdikleri derecelendirilmiş puanlama anahtarlarındaki (scoring rubrics) ölçütler doğrultusunda öğrencinin hazırlamasını istemelidir. Bu anahtarlar eşliğinde hazırlanan ödevlerin zamanla daha dizgesel ve nitelikli olması kaçınılmazdır. Özgün ve amaca uygun ödevleri dizgesel bir anahtardan yararlanarak yapmayı başarabilen öğrencinin özgüveni gelişir ve bireyleşme yolunda bir adım daha atmış olur.

Öğrenci başarısının adil biçimde değerlendirilmesi de çok önemlidir. Ödevlerin değerlendirilmesi sürecinde öğretmenler puanlamaya özel önem vermeli, değerlendirmede dereceli puanlama anahtarlarından yararlanmalıdır. $\mathrm{Bu}$ da öğretmenin amaca uygun, nesnel, geçerli ve güvenli dereceli puanlama anahtarlarının hazırlanması, geliştirilmesi ve puanlanması konusunda donanımlı olmasını gerektirir. Kutlu, Doğan ve Karakaya'ya (2010) göre, dereceli puanlama anahtarları, öğrencilere yaptıkları çalışmaların hangi ölçütlere göre değerlendirileceğini ve performanslarının hangi düzeydeki puana denk geldiğini gösteren araçlarıdır. Bu sayede öğrenciler puanlama sonunda, bulundukları başarı durumunu ve ulaşmaları gereken başarı (yetkinlik) düzeyini görebilirler. Turgut ve Baykul'a (2010:266) göre dereceli puanlama anahtarları ya da dereceleme ölçekleri, öğrencilerin yanıtlarını ve performanslarını belirlenen ölçütlere göre puanlamada kullanılacak bir kılavuzdur, öğrencilerin performanslarının hangi yetkinlikte olduğunu belirtir.

Özetle söylemek gerekirse, öğrenmesinin sorumluluğunu üstlenen, verilen görevi kendi çabasıyla yapabilen, bireysel öğrenmesini sürdüren, kendi kendisini değerlendirebilen; kendi gelişim durumuna, başarılı ve başarısız yanlarına ilişkin kararlar verebilen öğrenci özerk benliğini de geliştirir. Ayrıca, verilen ödevlerin, yazılı anlatım (kompozisyon) çalışmalarının ve yazılı sınavlardaki açık uçlu soruların değerlendirilmesinde de nesnel ve tutarlı olabilmek, öğrencinin güçlü ve zayıf olduğu yanları belirleyebilmek ve ona sağlıklı dönütler verebilmek için dereceli puanlama anahtarlarından yararlanmak, dil ve edebiyat öğretmeninin benimsemesi gereken temel bir ilke olmalıdır.

\section{SONUÇ}

Baskılayıcı, dayatmacı, kısıtlayıcı ve ezbere yönelten eğitim ortamları, öğrencilerin özerkleşmesinin önünde büyük engeller oluşturur. Çocukların/gençlerin özerk benlik duygusu gelişmiş bireylere evrilmelerinde çağdaş anlayışla yapılandırılmış dil ve edebiyat öğretimi 
ortamları çok önemli ve ayrıcalıklı bir yere sahiptir. Kişilerin duygu ve düşünce yönünden eğitilmesini, kültürel yönden gelişmesini sağlayan dil ve edebiyat öğretimi ortamlarında öğretmen, çok küçük yaşlardan başlayarak özerk olma isteğinde ve eğiliminde olan çocuğun bu isteğini karşılamaya dönük etkinlikler düzenlemeli; derslerini öğrencilerin özerklik duygusu geliştirmelerini sağlayacak biçimde kurgulamalıdır. Özerk bireyler yetiştirebilmek için dil ve edebiyat öğretimi ortamlarında öğrenciler yalnızca bilgiyle donatılmamalı; duygudan, düşünceden, sorgulamadan kopuk yetiştirilmemelidir. $\mathrm{Bu}$ ortamların öncelikle duygusal olarak güvenli, demokratik, sevgi dolu, içtenlikli, destekleyici ve özgür olması gerekir. Ancak o zaman öğrenciler, kendi öznellikleriyle, kendi özgünlükleriyle, kendi istekleriyle derslere katılır; bireyleşme sürecinde yol almaya başlarlar. En temel kişilik özelliklerinin çocukluk döneminde oluştuğu düşünüldüğünde dil ve edebiyat derslerinin bu anlayışla yapılandırılmasının önemi de kendiliğinden ortaya çıkmaktadır.

\section{KAYNAKÇA}

Adams, J. F. (1995). Ergenliği Anlamak. Çev: Ali Dönmez, Bekir Onur. Ankara: İmge Yayınları.

Aslan, C. (2006). Türkçe Ders Kitaplarında "Türkçe Olmayan Sözcükler"in Kullanımı Üzerine Bir İnceleme, Ankara Üniversitesi TÖMER Dil Dergisi, 133, 7-19.

Aslan, C. (2010a). Düşünme Becerilerini Geliștirici Dil ve Edebiyat Öğretimi Ortamları -Bir Eğitim Durumu Örneği-, Balıkesir Üniversitesi Sosyal Bilimler Enstitüsü Dergisi, (13)24, 127-152.

Aslan, C. (2010b). An analysis of Turkish and French literature textbooks' outer structure and visual elements, Procedia-Social and Behavioral Sciences, 2, 880-889. (Science Direct Journal), Published by Elsevier Ltd.

Aslan, C. (2011a). A Study of the Questions Asked by Mother Tongue Teachers in Examinations in Terms of Developing High Level Thinking Skills (Anadili Öğretmenlerinin Sınavlarda Sordukları Soruların Üst Düzey Düşünme Becerilerini Geliştirmesi Bakımından İncelenmesi). (Eds.: G. L. Uzun and Ü. Bozkurt) Theoretical and Applied Researches on Turkish Language Teaching (Türkçenin Eğitimi - Öğretiminde Kuramsal ve Uygulamalı Araștırmalar), Essen: Die Blaue Eule, 431-444.

Aslan, C. (2011b) Sanatsal Bir Uyaran Olarak Kısa Filmlerin Dil ve Edebiyat Öğretimi Ortamlarında Kullanılması -Bir Kısa Film ve Etkinlik Önerileri-, Prof. Dr. Cahit Kavcar Türkçe Eğitimi Çalıştayı, Ankara Üniversitesi Eğitim Bilimleri Fakültesi Yayını, No:319, 193-204.

Aslan, C. (2014). Türkiye'de Çocuk ve Gençlik Edebiyatında Duyarlı Konuların (Sensitive Issues) Ele Alınışı Üzerine Eleştirel Bir Yaklaşım, Eleştirel Pedagoji, 6 (32).

Bayraktaroğlu, S. (2015). Türkiye'de Yabancı Dil Eğitimi-Beklentiler, Gerçekler, Öneriler. Ankara: Öğretmen Dünyası Yayını.

Binyazar, A. (1983). Anadili Öğretiminde Yazınsal Alanlara Açlım, Türk Dili, 379-380, Ankara: TDK Yayını, AÜ Basımevi, s.57-72.

Coşkun, H. (1996). Eğitim Teknolojisi ve Kültürlerarası Eğitim Bağlamında İlköğretim İkinci Sınıf Türkçe ve Almanca Ders Kitaplarının İçerik Sorunları. Türkiye ve Almanya'da İlköğretim Ders Kitapları. Ankara: Türk-Alman Kültür İşleri Kurulu Yayın Dizisi No:11.

Cüceloğlu, D. (1998). İyi Düşün Doğru Karar Ver. İstanbul: Sistem Yayıncllık.

Çotuksöken, Y. (2002). Türkçe Üzerine Denemeler ve Eleștiriler. İstanbul: Papatya Yayıncılık.

De Beaugrande, R. ve Dressler, W. (1981). Introduction to text linguistics. London and New York: Longman Inc.

Durmuşçelebi, M. (2007). Türkiye ve Almanya'da İlköğretimde Anadili Öğretimi, Yayımlanmamış Doktora Tezi, Ankara Üniversitesi Sosyal Bilimler Enstitüsü.

Erdem, İ. ve Çelik, M. (2011). Dilbilgisi Öğretim Yöntemi Üzerine Değerlendirmeler, Turkish Studies, 6, 10301041.

Erkmen, N. (1996). Çağdaş Bir Ders Kitabı Nasıl Olmalı? Ders Kitabını Mükemmel Yapan Nitelikler, Türkiye ve Almanya'da İlköğretim Ders Kitapları, Ankara: Türk-Alman Kültür İşleri Kurulu Yayın Dizisi No:11.

Freire, P. (1995). Ezilenlerin Pedagojisi, (Çevirenler: D. Hattatoğlu ve E. Özbek.) İstanbul: Ayrıntı Yayıncılık.

Gander, M.J., Gardiner, H.W. (1998). Çocuk ve Ergen Gelişimi. (Çevirenler: A. Dönmez, N. Çelen, B. Onur) Ankara: İmge Kitapevi.

Göğüș, B. (1990). Anadili Eğitiminde Yetersizliklerimiz. Çağdaş Türk Dili, Cilt -III, Sayı: 30-31, s.870-873.

Göktürk, A. (1989). Sözün Ötesi. Yazılar. İstanbul: İnkılâp Kitabevi.

Günay, D. (2001). Metin Bilgisi. İstanbul: Multilingual Yayınları.

Günay, D. (2006). Liselerdeki Yazın Eğitimine Yeni Bir Yaklaşım, Milli Eğitim Dergisi, 34 (169). 
Güngör, Ö. (1998). 1. Sınıf Fransızca ve Türkçe Kitaplarının Karşılaştırılması. Dünyada ve Türkiye'de Anadili Eğitimi. Ankara Üniversitesi TÖMER, 45-49.

Güneyli, A., Özder, H., Konedralı, G. ve Arsan, N. (2010). İlköğretim Öğrencilerinin Türkçe ile Diğer Ders Başarıları Arasındaki İlişki, Mediterranean Journal of Educational Research, 7, 60-72.

İçmeli, M. (1996). Türkiye'de İlköğretim Kitaplarında Fiziksel Yapı, Tasarım ve İllüstrasyon Sorunları, Türkiye ve Almanya'da İlköğretim Ders Kitapları. Ankara: Türk-Alman Kültür İşleri Kurulu Yayın Dizisi No:11.

İnam, A. (2016). Bilinç Üzerine Düşünceler. Orta Doğu Teknik Üniversitesi Online Yayınlar. Bu makaleye 23.02.2016 tarihinde http://phil.metu.edu.tr/ahmet-inam/bilinc.htm ağ adresinden ulaşılmıştır.

İpşiroğlu, Z. (1991). Yazma Eylemi, Yazma Uğraşı. ÇYDD Yayını 3. İstanbul: Cem Yayınevi, 21-30.

İpşiroğlu, N. (2000). Alımlama Boyutları ve Çeşitlemeleri: Resim. İstanbul: Papirüs Yayınevi.

İşeri, K. (2003). Türkçe Ders Kitaplarındaki Metinler için Çizilen Resimlerin İncelenmesi. Cumhuriyetimizin 80. Yılında Türkçemiz, Anaçev Yayını.

Kagan, M. (1993). Estetik ve Sanat Dersleri. (Çeviren: Aziz Çalışlar) Ankara: İmge Kitabevi.

Karadüz, A. (2007). Dilbilgisi Öğretimi. İlköğretimde Türkçe Öğretimi. Ankara: PEGEMA Akademi.

Karagül, S. (2012). Özerk Benlik Gelişimi ve Yabancı Dilde Eğitim, Çağdaş Türk Dili, 288, 725-733.

Kavcar, C. (1988). Türk Dili ve Edebiyatı Öğretimi, Ankara üniversitesi Eğitim Bilimleri Fakültesi Dergisi, 20 (12), 261-273.

Kavcar, C. (1999). Edebiyat ve Eğitim. Ankara: Engin Yayınevi.

Kavcar, C. (2008). Türkçenin Güncel Sorunları, Çağdaş Türk Dili, 244, 152-158.

Keçik, İ. ve Uzun, L. (2003). Türkçe Yazılı ve Sözlü Anlatım, Eskişehir: Anadolu Üniversitesi Yayınları.

Kuntay, N. (1998). 5. Sınıf Türkçe ve Fransızca Anadili Kitaplarının Karşılaştırılması, Dünyada ve Türkiye'de Anadili Ĕ̆itimi, Ankara Üniversitesi TÖMER, 61-65.

Kutlu, Ö., Doğan, C. D. ve Karakaya, İ. (2010). Öğrenci Başarısının Belirlenmesi, Performansa ve Portfolyoya Dayalı Durum Belirleme. Ankara: Pegem Akademi.

MEB Talim Terbiye Kurulu Başkanlığı, 1-5. Sınıflar Türkçe Öğretim Programı, 2009.

MEB Talim Terbiye Kurulu Bașkanlığı, 6, 7, 8. Sınıflar Türkçe Öğretim Programı, 2009.

MEB Talim Terbiye Kurulu Başkanlığı, 9, 10, 11 ve 12. Sınıflar Türk Edebiyatı Dersi Öğretim Programı.

Morin, E. (2013). Geleceğin Eğitimi İçin Gerekli Yedi Bilgi. Çeviren: Hüsnü Dilli. İstanbul: Bilgi Üniversitesi Yayını, No: 21.

Nadi, N. (1974). Sokakta Gürültü Var. İstanbul: Çağdaş Yayınları.

Özbay, M. (2002). Yazılı Anlatım Becerisinin Geliştirilmesi, Prof. Dr. Sadık Tural Armağanı (Haz.: İ.Karakuş). Ankara.

Özbay, M. (2006). Özel Öğretim Yöntemleri II. Ankara: Öncü Kitabevi.

Özdemir, E. (1990). Anadili Öğretimimizdeki Ölü Nokta, Çağdaş Türk Dili. Cilt -III, Sayl: 30-31, 856-860.

Öztürk, O. (2009a). Bilim Adamının Kimlik Sorunu ve Dil Bilinci. [Online]: http://www.ayorum.com/haber oku.asp?haber=1453, 01.02.2016 tarihinde indirilmiștir.

Öztürk, O. (2009b). Benlik Özerkliği. [Online]: http://www.ayorum.com/haber_oku.asp?haber=1600, 01.02.2016 tarihinde indirilmiştir.

Öztürk, Orhan (2013). Özerk Benlik, Kul Benlik. İstanbul: Okuyan Us Yayınları.

Power, B. M. ve Hubbard, R. S. (2002). Language Development, A Reader for Teacher. Merrill Prentice Hall, Pearson Education.

Rogers, C. R. (1951). Client Centered Therapy. Boston: Houghton Miflin.

Sağır, M. (2002). Türkçe Dilbilgisi Öğretimi. Ankara: Nobel Yayın Dağıtım.

Sever, S. (2002). Öğretim Dili Olarak Türkçenin Sorunları ve Öğretme Öğrenme Sürecindeki Etkili Yaklaşımlar, Ĕ̆itim Bilimleri Fakültesi Dergisi, 34 (1-2), 11-22.

Sever, S., Kaya, Z. ve Aslan, C. (2008). Etkinliklerle Türkçe Öğretimi. İçinde A. Oktay ve Ö. Polat Unutkan (Ed.) Eğitim Durumu Örnekleri (4. Bölüm, s.133-239). İzmir: TUDEM Yayını.

Sever, S. ve Aslan, C. (2009). Eleştirel Düşünme Becerisini Kazandırma Bağlamında Çocuk Edebiyatı Yapıtlarının İșlevi Üzerine Bir Çözümleme, Türkiye'de Cocuk Yetiștirme, Yaklașımlar, Yöntemler, Sorunlar, Çözümler. VI. Ulusal Çocuk Kültürü Kongresi Bildirileri. (Yay. Haz.: M. Artar). Ankara Üniversitesi Çocuk Kültürü Araștırma ve Uygulama Merkezi Yayınları: 17, 231-250.

Sever, S. (2008) Çocuk ve Edebiyat. İzmir: Tudem Yayıncılık.

Strickland, D. S., Galda, L. ve Cullinan, B. E. (2004). Language Arts Learning and Teaching. Thomson Learning, Wadsworth Publishing.

Şimşek, N. (1997). Derste Eğitim Teknolojilerinin Kullanımı. Ankara: Nobel Yayın Dağıtım.

Tabak, G. ve Göçer, A. (2013). 6-8. Sınıflar Türkçe Dersi Öğretim Programının Ürün ve Süreç Odaklı Yazma Yaklaşımları Çerçevesinde Değerlendirilmesi, Ahi Evran Üniversitesi Kırşehir Eğitim Fakültesi Dergisi, 14(2), 147-169. 
Temizkan, M. (2012). Metin Temelli Dilbilgisi Öğretimi ve Uygulamaları. Editör: M. Özbay. Türkçe Eğitimi Açısından Dilbilgisi Öğretimi içinde. Ankara: PEGEMA Akademi.

Turgut, M. F. ve Baykul, Y. (2010). Eğitimde Ölçme ve Değerlendirme. Ankara: Pegem Akademi Yayını.

Ülper, H. (2011). Öğrenci Metinlerinin Tutarlılık Ölçütleri Bağlamında Değerlendirilmesi. Turkish Studies, 6 (4), 849-863.

Ülper, H. ve Yalınkılıç, K. (2010). Son İki Türkçe Programına Göre Hazırlanan Türkçe DERS Kitaplarındaki Metin Sonu Sorularının Nicel ve Nitel Görünümü, Uluslararası Sosyal Araştırmalar Dergisi, 3 (12).

Yazar, İ. (2003). Türk Dili ve Edebiyatı Ders Kitaplarına Görsel Açıdan Bir Yaklaşım. I. Sosyal Bilimler Eğitimi Kongresi, Dokuz Eylül Üniversitesi Buca Eğitim Fakültesi, İzmir.

Yllmaz, E. (2010). Uygulamalı Metin Bilgisi. Ankara: Pegem Akademi.

Yörükoğlu, A. (2004). Gençlik Çağı Ruh Sağliğı ve Ruhsal Sorunlar. İstanbul; Özgür Yayınları.

\section{Sözlükler}

Türkçe Sözlük (2012) Ankara: Dil Derneği Yayınları: 23, 3. Baskı Dil Derneği Türkçe Sözlük. Türk Dil Kurumu Türkçe Sözlük (2015).

TÜBA Türkçe Bilim Terimleri Sözlüğü. 